\title{
Critical Peak Electricity Pricing for Sustainable Manufacturing: Modeling and Case Studies
}

\author{
Yong Wang ${ }^{\mathrm{a}}$, and $\mathrm{Lin}_{\mathrm{Li}}{ }^{\mathrm{b}}$ ** \\ ${ }^{a}$ Department of Systems Science and Industrial Engineering, Binghamton University, \\ Binghamton, NY 13902, USA \\ ${ }^{\mathrm{b}}$ Department of Mechanical and Industrial Engineering, University of Illinois at Chicago, \\ Chicago, IL 60607, USA
}

\begin{abstract}
Critical peak pricing (CPP) is an electricity demand response technology that has great potential to lower the electricity cost and eliminate the need for more GHG emitting power plants. Many utilities start to offer CPP as the default electric service for industrial customers in their market design. When a manufacturing customer defaults to CPP, it is vital to understand what it is and how it will influence their energy budget and facility operations. In addition, given the option to opt-out to a time-of-use (TOU) rate, it is not always easy to tell whether the switch will result in higher bills or more GHG emissions. These questions will be answered in this paper. Specifically, we will model and compare both CPP and TOU rates to gain more accurate knowledge regarding annual electric costs and GHG emissions. With these results, manufacturing enterprises will be able to make more informed decisions on which service to choose and how to use electricity while fulfilling their role for sustainability by enrolling. The case study results show that for industrial customers with production flexibility, with proper rescheduling of electric use, they can save money by adopting CPP, while contributing to reducing GHG emissions. The savings on the annual electric bill can be $30.45 \%$ with a simultaneous GHG emissions reduction of $5.63 \%$ for an average industrial customer.
\end{abstract}

Keywords: Manufacturing; Sustainability; Critical peak pricing; Time-of-use; Demand response

\section{Introduction}

Climate change is a global threat facing the human race. It has caused serious impacts that harm economies around the world $[1,2]$. Reducing greenhouse gas (GHG) emissions is the key to tackling the challenge [3-5], i.e., bioelectrochemical technique was reviewed in [4] to reduce carbon dioxide emissions. Combating climate change has become an indispensable main topic of the high-level international and intergovernmental events such as Asia-Pacific Economic Cooperation (APEC) Summit [6], the G-20 Summit [7], and the United Nations Climate Summit [8]. The seriousness of the challenge has urged both developed and developing countries to take solid actions to curb GHG emissions. For example, among a series of recent plans revealed to fight climate change, European Union has set a target of 20\% cut in GHG emissions by 2020 compared with 1990 [9]. The U.S. pledged to cut total GHG emissions by $26 \%-28 \%$ below its 2005 level in 2025 [10]. China pledged to reach its emission peak by 2030. These three economies jointly contribute about 50\% of the world's total GHG emissions [11].

Electricity generation is a major source of GHG emissions worldwide. For example, in the U.S, it is responsible for 38\% of total energy-related emissions in 2013 [12]. Electric demand

\footnotetext{
* Corresponding author. Tel: +1 312-996-3045; Fax: +1 312-413-0447. Address: ERF 3057, 842 W Taylor St, Chicago, IL 60607-7022, USA. Email: linli@uic.edu.
} 
oscillates vastly from season to season in a year and from hour to hour in a day [13]. The demand typically peaks from late afternoon to early evening during summer months, when extremely hot weather prompts high air-conditioning use that strains the electric grid. As an example, the total electric load of California Independent System Operator (CAISO) in the U.S. during year 2012 [14] is shown in Figure 1. The capacity reserved for the peak load is used only occasionally and then idled for the rest of the year. In the case of CAISO, the top $10 \%$ of the electric capacity is only needed for 67 hours, which is only $0.76 \%$ of the time in the year. The electric price during peak hours can be extremely high. In some cases, the electric charges of the top 12 peak hours during a year can account for as high as $23 \%$ of a customer's annual electric bill [15].

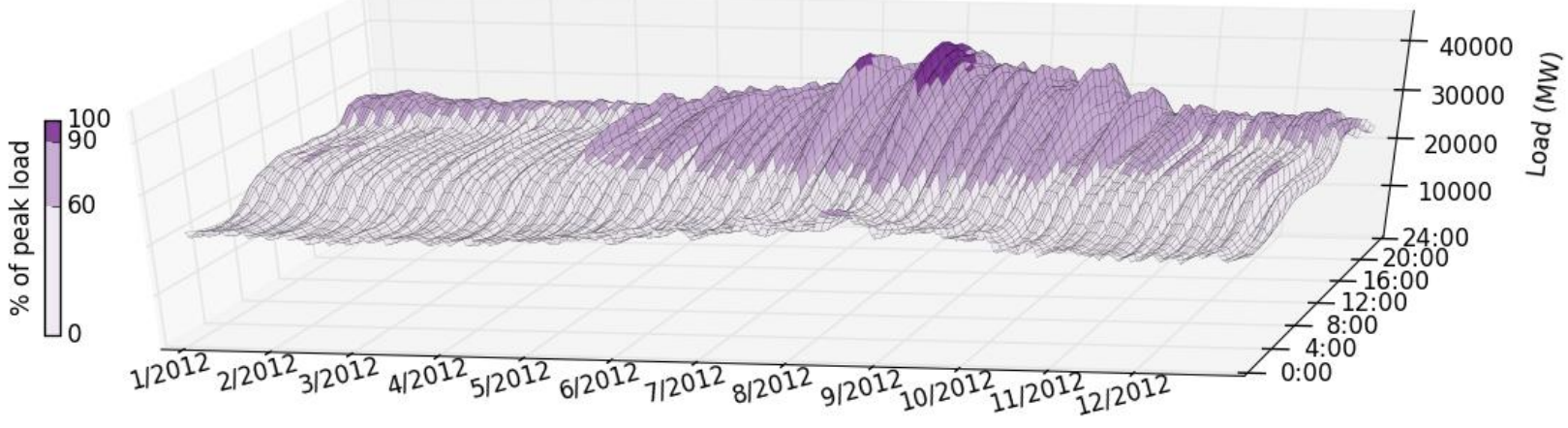

Figure 1. Hourly total electric load on the CAISO market (Raw data is in [14])

New technologies that can constructively reduce GHG emissions start to emerge in the electric power industry. One such technology is demand response [16-18]. Demand response emerges as a smart grid technology to better balance electricity supply and demand. It encourages electric customers to reduce or shift electricity usage during peak hours in exchange for various economic benefits $[19,20]$. By doing so, the need for more expensive and more GHG-intensive peaking power plants can be avoided. According to a staff report of the U.S. Federal Energy Regulatory Commission (FERC) [21], as much as $150 \mathrm{GW}$ of the peak load could be reduced by 2019 through demand response in the U.S., which is equivalent to the capacity of 2,000 peaking power plants! Demand response also provides a viable way to integrate intermittent renewable sources as their market penetrations continue to increase [22]. This in turn helps decrease GHG emissions.

The introduction of demand response has been boosted in the past few years by the advancement of enabling technology. Both U.S. and EU have invested heavily to promote the deployment of smart meters $[23,24]$. The adoption of smart meters in developing countries such as China is also catching up [25]. Demand response has many different forms of implementation [16, 26, 27]. Two such forms are time-of-use (TOU) pricing and critical peak pricing (CPP).

Unlike the flat rates where the price of electricity stays constant throughout the day, dynamic pricing is more commonly adopted in demand response programs to represent the dynamic cost of power generation [28-30]. For example, the electric charges in TOU pricing are differentiated by on-, mid-, and off-peak periods, with the on-peak price being the highest and the off-peak price being the lowest [31]. The time and pricing blocks are kept unchanged every workday for a season or a year. CPP is an overlay on the TOU pricing. It imposes a much higher rate during a period called the critical peak in an event day, when the electricity use is significantly high. With CPP, the time and duration of the critical peak period within an event 
day are predetermined, so is the maximum number of event days per year, but the specific dates when the events will occur are not. The customers will be informed one day ahead of the event. Although the electric price is much higher during the critical-peak period in event days, the customers are offered discounted prices during other days in the rest of the year. Therefore, it enables the customers to significantly reduce their total electric bill by restraining electric use during CPP events. Many customers embracing sustainability leadership are at the vanguard of CPP applications [32-35].

Utility companies usually create different tariffs for residential and business customers, highlighting the different characteristics specific to each of these two sectors $[36,37]$. This paper studies CPP for business applications, with a special focus on industrial manufacturing customers. More specifically, we start with a literature review of CPP for industrial demand response. Then, we collect typical CPP tariffs from several utility companies that represent a wide range of tariff design. We also analyze the common components presented in the CPP tariffs and their differences with TOU tariffs. The detailed rate schedule information is tabulated for future reference. After that, we conduct a survey of CPP events and characterize their patterns. Case studies using a series of manufacturing systems have been conducted to illustrate how to choose between CPP and TOU rates when both options are provided to industrial customers. Finally, the economic and environmental benefits from adopting CPP have been quantified.

\section{Brief literature review of CPP research}

Related research on CPP demand response programs in the U.S. has been previously conducted by some researchers and organizations. For example, Herter et al. [38-40] studied customer response during CPP events in California. Aghaei and Alizadeh [41] investigated the application of a new form of CPP demand response program announced by U.S. FERC in the cost-emissionbased unit commitment problem. Faruqui et al. [42] analyzed two dynamic pricing rates and an enabling technology in Michigan. Steve et al. [43] develop econometric models to examine the responses of participants in CPP programs in Minnesota and South Dakota. Wolak [44] reported an experiment that evaluates the performance of CPP programs in Washington DC for households that differ in terms of income levels, electricity using appliance holdings, and whether they own a smart thermostat. On the other hand, dynamic pricing in Europe and China are mainly focused on TOU tariffs [45-47] and the data of CPP programs is limited. The progress of pioneer work in dynamic pricing in Asia (e.g., China, Japan, Korea, and Indonesia) is summarized in [48].

In addition, all the above-mentioned efforts focus on residential programs targeting household applications. The CPP programs targeting industrial customers have been largely neglected. Industrial electricity use is fundamentally different from residential electricity use [39, 40, 49]. For example, electricity is a major form of energy source in manufacturing activities. Manufacturing processes such as machining and assembly involve utilizing equipment that is much more energy-intensive. Business customers together contribute $83 \%$ to the potential peak demand reduction for CPP programs in 2012 in the U.S.; in comparison, the contribution of residential customers is only $17 \%$ [50]. Besides, most of manufacturing businesses run multiple shifts [51-53] and have less flexibility with their production processes than the operation of residential appliances such as air conditioners, refrigerators, washers, dryers, and ovens [54, 55]. 
Therefore, studies show that it is still challenging to simultaneously coordinate production activities, energy consumption, and environment impacts to achieve manufacturing sustainability [56-58].

It should be mention that related work on non-residential CPP has been previously conducted by a few researchers and organizations. Examples include [59-61]. However, all these efforts focus on evaluating the load impacts of such programs from the utility's perspective. The assessment of the benefits to customers, especially industrial manufacturing customers, is limited.

Some of our initial work have modeled the dynamics of typical manufacturing systems [62]. The TOU based electricity cost of manufacturing systems $[63,64]$ is analyzed. With the modeling result, we have also discussed whether it is economical for an industrial customer to switch from the flat rate to the voluntary TOU rate $[65,66]$. However, as smart meter penetration increases in the U.S., many utilities are in a transition to fade out the flat rate, and replace it by mandatory TOU or CPP rates. Therefore, it would be worthwhile to take into account this new trend, which has been largely neglected in our previous work.

According to the nationwide FERC demand response survey [50], TOU pricing is currently the most prevalent time-varying rate. In comparison, CPP is relatively new, but its adoption is gaining momentum. Many utilities start to offer CPP as the default electric service in their market design, unless customers explicitly opt-out to a TOU rate. When a manufacturing customer defaults to CPP, it is vital to understand what it is and how it will influence their energy budget and facility operations. In addition, given the option to opt-out to a TOU rate, it is not always easy to tell whether the switch will result in higher bills. These questions will be answered in this paper. Specifically, we will model and compare both CPP and TOU rates to gain more accurate knowledge regarding annual electric costs and related GHG emissions. With these results, manufacturing enterprises will be able to make more informed decisions on which service to choose and how to use electricity while fulfilling their role for sustainability by enrolling.

\section{Industrial CPP in California}

As mentioned in the previous section, CPP programs are more commonly available in the U.S. than in the other parts of the world. Based on the U.S. FERC survey results [50], we list the numbers of customers enrolled in the business CPP programs by state in Figure 2. The figure shows there are 11 states providing CPP programs for business customers. California has the most enrolled customers, making up over $75 \%$ of the total. In addition, no other states have kept a detailed, transparent, long-term record of CPP events as well as easily accessible GHG emission data of their generators. Therefore, we will focus on examining CPP programs offered in California as case studies to gain the insights for manufacturers that are currently enrolled or considering enrolling in CPP in other states as well as for utilities that are currently offering or considering offering CPP in other states. 


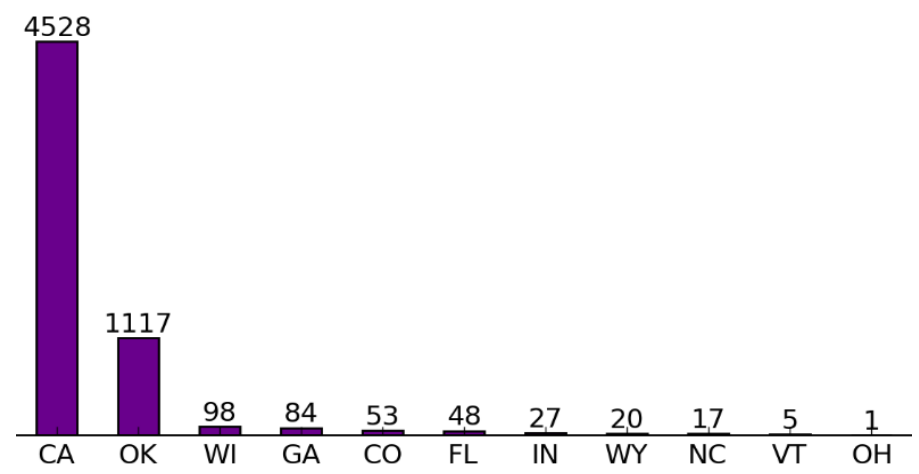

Figure 2. Numbers of business customers enrolled in CPP by state (Raw data is in [50])

There are three major utilities in California, Pacific Gas \& Electric (PGE), Southern California Edison (SCE), and San Diego Gas \& Electric (SDGE). They are all investor-owned utilities operating in the CAISO grid and regulated by California Public Utilities Commission (CPUC) $[67,68]$. They have each designed CPP based on their own pricing models. We will examine the industrial CPP programs of all three. Although the rate schedule terms of the three utility vary, they all have some key elements in common. All three utilities automatically place industrial customers on CPP by default, but customers are allowed to opt out to a TOU rate. However, participation in one of the two rates is mandatory. Table 1 lists the names of the default CPP and corresponding optional TOU rates of PGE, SCE, and SDGE for industrial customers.

In Table 1, the first two columns list the utility names as well as the tariffs that contain the CPP and TOU clauses. The tariff names will be used as the index for further analysis in subsequent tables. Utilities usually divide the customers into several categories based on the customers' peak demand (the Demand Range column in Table 1), and design a different tariff for each category. For example, in SCE, the tariffs TOU-GS-1, TOU-GS-2, TOU-GS-3, and TOU-8 are applicable to industrial customers with peak demand in the intervals $[0,20] \mathrm{kW},(20,200) \mathrm{kW},[200,500]$ $\mathrm{kW}$, and $(500, \infty) \mathrm{kW}$, respectively. The customer's peak demand is the measured highest demand during the billing month by a demand meter with a 15 -minute metering interval. These tariffs are extracted from the publically available rate books on the associated official websites of these three utilities. Note that cancelled, closed, and expired tariffs are excluded from the list.

Table 1. Industrial CPP and TOU tariffs of PGE, SCE, and SDGE

\begin{tabular}{|c|c|c|c|c|}
\hline Utility & Tariff Name & TOU Clause & CPP Clause & Demand Range (kW) \\
\hline \multirow{4}{*}{ PGE [69] } & A-1 & TOU & PDP & {$[0,200)$} \\
\cline { 2 - 5 } & A-6 & TOU & PDP & {$[200,500)$} \\
\cline { 2 - 5 } & A-10 & TOU & PDP & {$[200,500)$} \\
\cline { 2 - 5 } & E-19 & TOU & PDP & {$[500,1000)$} \\
\cline { 2 - 5 } & E-20 & TOU & PDP & {$[1000, \infty)$} \\
\hline \multirow{4}{*}{ SCE [70] } & TOU-GS-1 & Option A & Option CPP & {$[0,20]$} \\
\cline { 2 - 5 } & TOU-GS-2 & Option B & Option CPP & $(20,200)$ \\
\cline { 2 - 5 } & TOU-GS-3 & Option B & Option CPP & {$[200,500]$} \\
\cline { 2 - 5 } & TOU-8 & Option B & Option CPP & $(500, \infty)$ \\
\hline SDGE [71] & AL-TOU & EECC & EECC-CPP-D & {$[20, \infty)$} \\
\hline
\end{tabular}




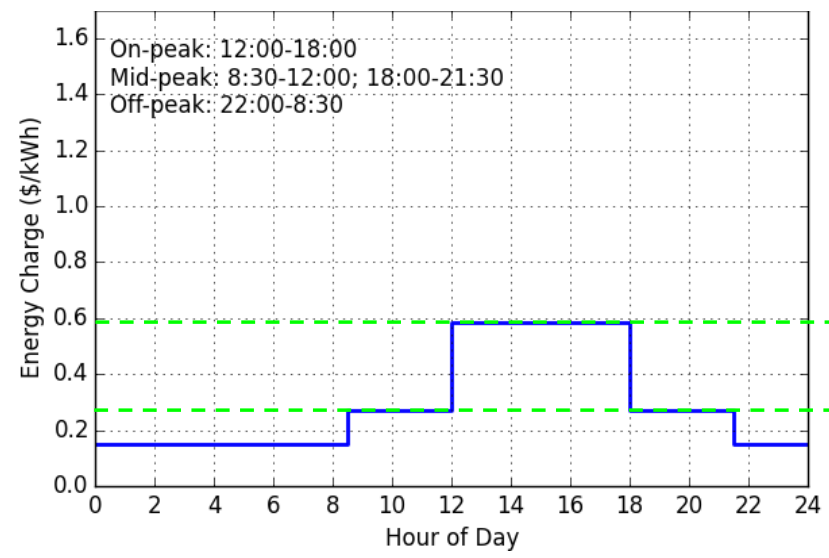

(a)

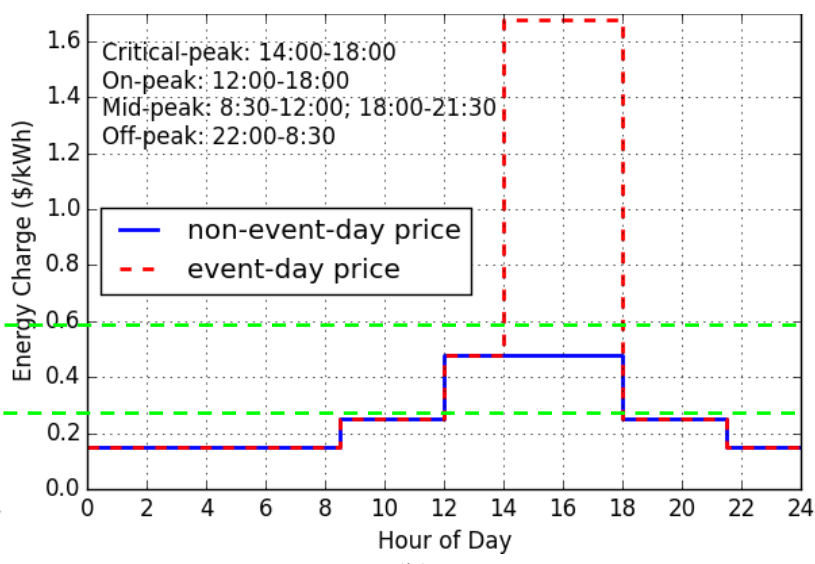

(b)

Figure 3. (a) TOU and (b) CPP charge profiles of PGE's A-6 tariff during summer months (Raw data is in [69])

As an example, the TOU and CPP electric charge profiles of Pacific Gas \& Electric Company's (PGE) A-6 tariff during summer months are shown in Figure 3. Two auxiliary green lines are drawn to highlight the differences during mid- and on-peak periods.

Detailed pricing information of the TOU rates identified in Table 1 is summarized in Table 2. These rates can be explained as follows:

(i) All three utilities divide the entire year into two seasons, with May through October or June through September being the summer season, and the rest being the winter season.

(ii) The division of the on-, mid-, and off-peak periods varies. But on-peak periods generally consist of afternoon and early evening hours, off-peak periods consist of night hours, and mid-peak periods are in between. For all three utilities, off-peak periods also include all day of Saturdays, Sundays, and non-weekend holidays.

(iii) Most TOU rates contain the energy charge, the demand charge, and the customer charge. A customer's monthly bill is the sum of these three components. The energy and demand charges in the summer months are usually higher than those during the same period in the winter months. The energy and demand charges are collected for bundled services including electricity generation, transmission, and distribution.

(iv) The energy charge is applied to the energy (in $\mathrm{kWh}$ ) portion of electric use. The total daily energy charge is rendered by adding the three components corresponding to the on-, mid-, and off-peak periods, respectively.

(v) The demand charge is applied to the demand (in $\mathrm{kW}$ ) portion of electric use. The total monthly demand charge is rendered by adding the four components: the on-, mid-, offpeak period charges and the base charge. The on-, mid-, and off-peak-period components apply to the maximum demand during any on-, mid-, and off-peak hours of the month, respectively. The base component applies to the maximum demand during any time of the month.

(vi) The monthly customer charge represents the costs for various services such as meter reading, account billing, and call centers. It is fixed for a certain tariff, no matter how much electricity is use. However, for different tariffs in the same utility company, the customer charge increases as the demand range ramps up. 
Detailed pricing information of the CPP rates is summarized in Table 3. These rates are further explained as follows:

(i) Each CPP rate is superimposed on the corresponding TOU rate of the same utility, but the CPP rate also contains many additional clauses that are more complicated. In general, customers will pay an energy surcharge or adder for the portion used within the critical-peak period during the event days, and they will receive discounts or credits for electricity use on non-event days during the summer months.

(ii) Each CPP event lasts for four hours (14:00-18:00) for PGE and SCE customers, and seven hours (11:00-18:00) for SDGE customers. During a CPP event, the energy charge can be an order of magnitude higher than the corresponding TOU summer on-peak rates.

(iii) The credits are applied to days in summer months only. The credits may apply to onpeak periods only, both on- and mid-peak periods, or all three periods. The credits could be in the form of energy charge discounts, demand charge discounts, or both.

(iv) The number of CPP event days per year may be fixed or variable. For PGE, the number will be in the range $[9,15]$. For SCE, there will be exactly12 events per year. For SDGE, a maximum of 18 CPP events may be called. The event day can be any day year round for PGE and SDGE, and any non-holiday weekdays for SCE. 
Table 2. Detailed TOU rates (Note: Empty cells are interpreted as zero or not applicable)

\begin{tabular}{|c|c|c|c|c|c|c|c|c|c|c|c|c|c|}
\hline \multirow{2}{*}{ Utility } & \multirow{2}{*}{ Tariff } & \multirow{2}{*}{ Months } & \multirow{2}{*}{ On-peak } & \multirow{2}{*}{ Mid-peak } & \multirow{2}{*}{ Off-peak } & \multicolumn{3}{|c|}{ Energy Charge $(\$ / \mathbf{k W h})$} & \multicolumn{4}{|c|}{ Demand Charge $(\$ / \mathbf{k W})$} & \multirow{2}{*}{$\begin{array}{l}\text { Other Monthly } \\
\text { Charge (\$) }\end{array}$} \\
\hline & & & & & & On-peak & Mid-peak & Off-peak & On-peak & Mid-peak & Off-peak & Base (any time) & \\
\hline \multirow{10}{*}{ PGE } & \multirow{2}{*}{ A-1 } & May-Oct & $12-18$ & $8: 30-12 ; 18-21: 30$ & $21: 30-8: 30$ & 0.2547 & 0.24562 & 0.21801 & & & & & \multirow{2}{*}{19.975232} \\
\hline & & Nov-Apr & & $8: 30-21: 30$ & $21: 30-8: 30$ & & 0.17359 & 0.15381 & & & & & \\
\hline & \multirow{2}{*}{ A-6 } & May-Oct & $12-18$ & $8: 30-12 ; 18-21: 30$ & $21: 30-8: 30$ & 0.58648 & 0.2723 & 0.15207 & & & & & \multirow{2}{*}{26.08776} \\
\hline & & Nov-Apr & & $8: 30-21: 30$ & $21: 30-8: 30$ & & 0.17408 & 0.14207 & & & & & \\
\hline & \multirow{2}{*}{ A-10 } & May-Oct & $12-18$ & $8: 30-12 ; 18-21: 30$ & $21: 30-8: 30$ & 0.17989 & 0.17198 & 0.14792 & & & & 14.28 & \multirow{2}{*}{169.790688} \\
\hline & & Nov-Apr & & $8: 30-21: 30$ & $21: 30-8: 30$ & & 0.1308 & 0.11017 & & & & 6.47 & \\
\hline & \multirow{2}{*}{ E-19 } & May-Oct & $12-18$ & $8: 30-12 ; 18-21: 30$ & $21: 30-8: 30$ & 0.16594 & 0.11342 & 0.07903 & 18.37 & 4.25 & & 12.99 & \multirow{2}{*}{629.236224} \\
\hline & & Nov-Apr & & $8: 30-21: 30$ & $21: 30-8: 30$ & & 0.10645 & 0.08296 & & 0.22 & & 12.99 & \\
\hline & \multirow{2}{*}{ E-20 } & May-Oct & $12-18$ & $8: 30-12 ; 18-21: 30$ & $21: 30-8: 30$ & 0.15145 & 0.10722 & 0.07807 & 17.91 & 3.89 & & 12.65 & \multirow{2}{*}{1028.731136} \\
\hline & & Nov-Apr & & $8: 30-21: 30$ & $21: 30-8: 30$ & & 0.10094 & 0.07925 & & 0.25 & & 12.65 & \\
\hline \multirow{8}{*}{ SCE } & \multirow{2}{*}{ TOU-GS-1 } & Jun-Sep & $12-18$ & $8-12 ; 18-23$ & $23-8$ & 0.24438 & 0.19989 & 0.17031 & & & & & \multirow{2}{*}{27.208} \\
\hline & & Oct-May & & $8-21$ & $21-8$ & & 0.16766 & 0.15631 & & & & & \\
\hline & \multirow{2}{*}{ TOU-GS-2 } & Jun-Sep & $12-18$ & $8-12 ; 18-23$ & $23-8$ & 0.1457 & 0.09447 & 0.06933 & 19.9 & 5.82 & & 12.71 & \multirow{2}{*}{267.53} \\
\hline & & Oct-May & & $8-21$ & $21-8$ & & 0.09973 & 0.07503 & & & & 12.71 & \\
\hline & \multirow{2}{*}{ TOU-GS-3 } & Jun-Sep & $12-18$ & $8-12 ; 18-23$ & $23-8$ & 0.14656 & 0.09156 & 0.06538 & 20.36 & 5.97 & & 15.77 & \multirow{2}{*}{432.01} \\
\hline & & Oct-May & & $8-21$ & $21-8$ & & 0.09337 & 0.07077 & & & & 15.77 & \\
\hline & \multirow{2}{*}{ TOU-8 } & Jun-Sep & $12-18$ & $8-12 ; 18-23$ & $23-8$ & 0.15267 & 0.09289 & 0.06592 & 25.16 & 7.11 & & 14.99 & \multirow{2}{*}{596.11} \\
\hline & & Oct-May & & $8-21$ & $21-8$ & & 0.09454 & 0.07165 & & & & 14.99 & \\
\hline \multirow[b]{2}{*}{ SDGE } & \multirow[b]{2}{*}{ AL-TOU } & May-Oct & $11-18$ & 6-11;18-22 & $22-6$ & 0.12849 & 0.11807 & 0.08777 & 21.1 & & & 20.77 & {$[20,500) \mathrm{kW}: 87.83$; } \\
\hline & & Nov-Apr & $17-20$ & $6-17 ; 20-22$ & $22-6$ & 0.11845 & 0.10184 & 0.07896 & 7.14 & & & 20.77 & $\begin{array}{l}{[500,12000] \mathrm{kW}:} \\
349.31\end{array}$ \\
\hline
\end{tabular}

Table 3. Detailed CPP rates (Note: Empty cells are interpreted as zero or not applicable)

\begin{tabular}{|c|c|c|c|c|c|c|c|}
\hline Utility & Tariff & \begin{tabular}{|l|} 
Discount \\
Months
\end{tabular} & Energy and Demand Charge Credits & Adder During CPP Events & \begin{tabular}{|l|} 
Event Days \\
per Year
\end{tabular} & Event Time Period & $\begin{array}{l}\text { Notification } \\
\text { Time }\end{array}$ \\
\hline \multirow{5}{*}{ PGE } & A-1 & May-Oct & Energy Charge $(\$ / \mathrm{kWh}):$ All periods 0.00977 & Energy Charge (\$/kWh): 0.60 & \multirow{5}{*}[9,15]{} & \multirow{5}{*}{$\begin{array}{l}14-18, \text { Year round, } \\
\text { any day of the week }\end{array}$} & \multirow{5}{*}{$\begin{array}{l}\text { By } 14: 00 \text { day } \\
\text { ahead }\end{array}$} \\
\hline & A-6 & May-Oct & $\begin{array}{l}\text { Energy Charge (\$/kWh): On-peak 0.10830; Mid-peak } \\
0.02166\end{array}$ & Energy Charge (\$/kWh): 1.20 & & & \\
\hline & A-10 & May-Oct & $\begin{array}{l}\text { Energy Charge }(\$ / \mathrm{kWh}): \text { All periods } 0.00702 \\
\text { Demand Charge }(\$ / \mathrm{kW}): 2.6\end{array}$ & Energy Charge (\$/kWh): 0.90 & & & \\
\hline & E-19 & May-Oct & Demand Charge (\$/kW): On-peak 6.37; Mid-peak: 1.38 & Energy Charge (\$/kWh): 1.20 & & & \\
\hline & E-20 & May-Oct & Demand Charge (\$/kW): On-peak 6.10; Mid-peak: 1.24 & Energy Charge (\$/kWh): 1.20 & & & \\
\hline \multirow{4}{*}{ SCE } & TOU-GS-1 & Jun-Sep & Energy Charge $(\$ / \mathrm{kWh}):$ All periods 0.03776 & Energy Charge (\$/kWh): 1.37453 & \multirow{4}{*}{12} & \multirow{4}{*}{$\begin{array}{l}\text { 14-18, Year round, } \\
\text { non-holiday } \\
\text { weekdays }\end{array}$} & \multirow{4}{*}{$\begin{array}{l}\text { By } 15: 00 \text { day } \\
\text { ahead }\end{array}$} \\
\hline & TOU-GS-2 & Jun-Sep & Demand Charge (\$/kW): On-peak 10.75 & Energy Charge (\$/kWh): 1.37453 & & & \\
\hline & TOU-GS-3 & Jun-Sep & Demand Charge (\$/kW): On-peak 11.44 & Energy Charge $(\$ / \mathrm{kWh}): 1.37453$ & & & \\
\hline & TOU-8 & Jun-Sep & Demand Charge $(\$ / \mathrm{kW})$ : On-peak 11.93 & Energy Charge $(\$ / \mathrm{kWh}): 1.37453$ & & & \\
\hline SDGE & AL-TOU & May-Oct & Demand Charge (\$/kW): On-peak 11.30 & Energy Charge (\$/kWh): 1.39243 & {$[0,18]$} & $\begin{array}{l}\text { 11-18, Year round, } \\
\text { any day of the week }\end{array}$ & $\begin{array}{l}\text { By 15:00 day } \\
\text { ahead }\end{array}$ \\
\hline
\end{tabular}


(v) All three utilities notify customers on a day-ahead basis when a CPP event will occur the next day. Most likely customers will be notified through phone calls or emails. Some utilities also use additional communication tools such as SMS texts, pagers, fax, and utility websites.

(vi) Severe weather is the mostly quoted CPP event trigger. For example, the weather condition in PGE tariffs is based on the average of the day-ahead maximum temperature forecasts for San Jose, Concord, Red Bluff, Sacramento and Fresno. Events on nonholiday weekdays will be triggered at $98{ }^{\circ} \mathrm{F}\left(36.7^{\circ} \mathrm{C}\right)$, and will be triggered at $105{ }^{\circ} \mathrm{F}$ $\left(40.6^{\circ} \mathrm{C}\right)$ on holidays and weekends. A CPP event can also be triggered on a day-ahead basis by high load, high prices, a major system outage, or to meet annual event limits for a calendar year.

(vii) All three utilities provide a one-time guaranteed bill protection for default CPP customers for the first 12 consecutive months. This means that if a customer ends up paying more at the end of the first 12 consecutive months on a CPP rate, the utility will compensate the customer for all charges that exceed the customer's previous rate plan. The one-year bill protection works as a stimulus to encourage customers to enroll and find out if CPP is a good fit for their businesses.

\section{CPP events}

PGE, SCE, and SDGE are required to regularly report the operation status of their demand response programs to CPUC. We have examined the available reports and extracted the historical CPP event data from 2005 to 2014 for each of the three utilities [72, 73]. These data are tabulated in Tables A1 through A3 in Appendix. A summary of these three utilities in the CAISO grid is shown in Table 4. These data will be used for case studies in Section 5 to calculate the annual electric bills of manufacturing systems and the corresponding GHG emissions.

Table 4. Summary of the numbers of CPP events in the CAISO grid

\begin{tabular}{|cccccccccccc|}
\hline Utility & $\mathbf{2 0 0 5}$ & $\mathbf{2 0 0 6}$ & $\mathbf{2 0 0 7}$ & $\mathbf{2 0 0 8}$ & $\mathbf{2 0 0 9}$ & $\mathbf{2 0 1 0}$ & $\mathbf{2 0 1 1}$ & $\mathbf{2 0 1 2}$ & $\mathbf{2 0 1 3}$ & $\mathbf{2 0 1 4}$ & Sum \\
\hline PGE & 9 & 15 & 12 & 11 & 12 & 9 & 9 & 11 & 9 & 10 & 107 \\
SCE & 12 & 12 & 12 & 12 & 12 & 12 & 12 & 12 & 12 & 12 & 120 \\
SDGE & 5 & 11 & 11 & 0 & 8 & 4 & 2 & 9 & 4 & 6 & 60 \\
CAISO Total & 26 & 38 & 35 & 23 & 32 & 25 & 23 & 32 & 25 & 28 & 287 \\
\hline
\end{tabular}

Based on Tables 4 as well as A1 through A3, we plot the numbers of historical events of the utilities by month and by weekday in Figures 4 through 7. Based on these historical event data, we observe the following:

(i) SCE issued the most CPP events while SDGE issued the least in the ten-year record.

(ii) With a list of federal holidays [74] in Table A4 in Appendix, we find that no event of PGE or SCE fall in an observed holiday; while for SDGE, only one event date, 9/3/2007, is also an observed holiday (Labor Day). Based on the figures, we also find that no event of PGE or SCE fall during the weekend, while SDGE issued five Saturday events. This may be due to the relatively small reserved capacity of SDGE and its service area is densely populated.

(iii) Although all three utilities' tariffs claim CPP events may be called year round, in reality such events only occurred during the months of May through October, with an exception of a February event in SDGE. 
(vi) The by-month data appears to be approximately normally distributed for all three utilities and their sum. The patterns in Figures 4 through 6 reveal that the maximum number of events appears to shift from July and August to August and September. Figure 7 shows that about $96 \%$ of the total 287 events in CAISO occurred in June through September. It also shows that August has the most CPP events called, followed by July, September, and June.

(v) The by-weekday data is approximately uniformly distributed for PGE and SCE events, and they are slightly skewed towards Thursday and Friday for SDGE and CAISO events.

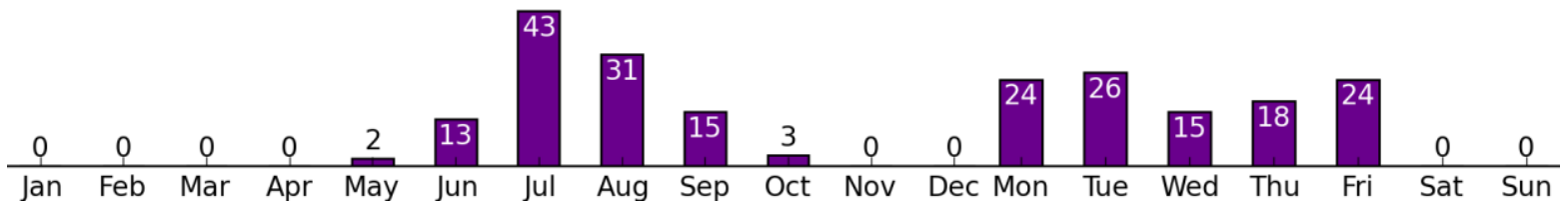

(a)

(b)

Figure 4. Numbers of historical events in PGE (a) by month and (b) by weekday

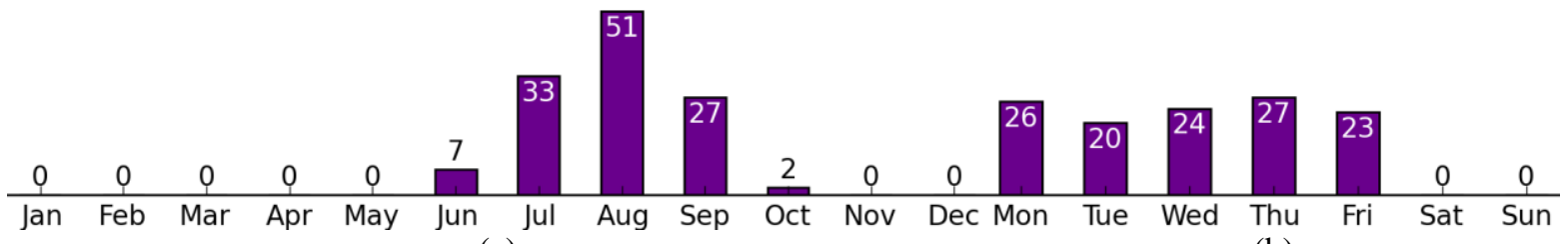

(a)

(b)

Figure 5. Numbers of historical events in SCE (a) by month and (b) by weekday

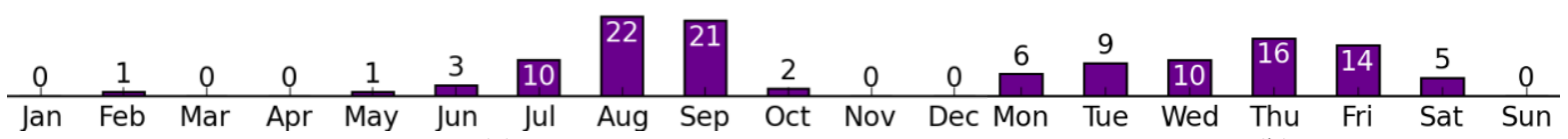

(a)

(b)

Figure 6. Numbers of historical events in SDGE (a) by month and (b) by weekday

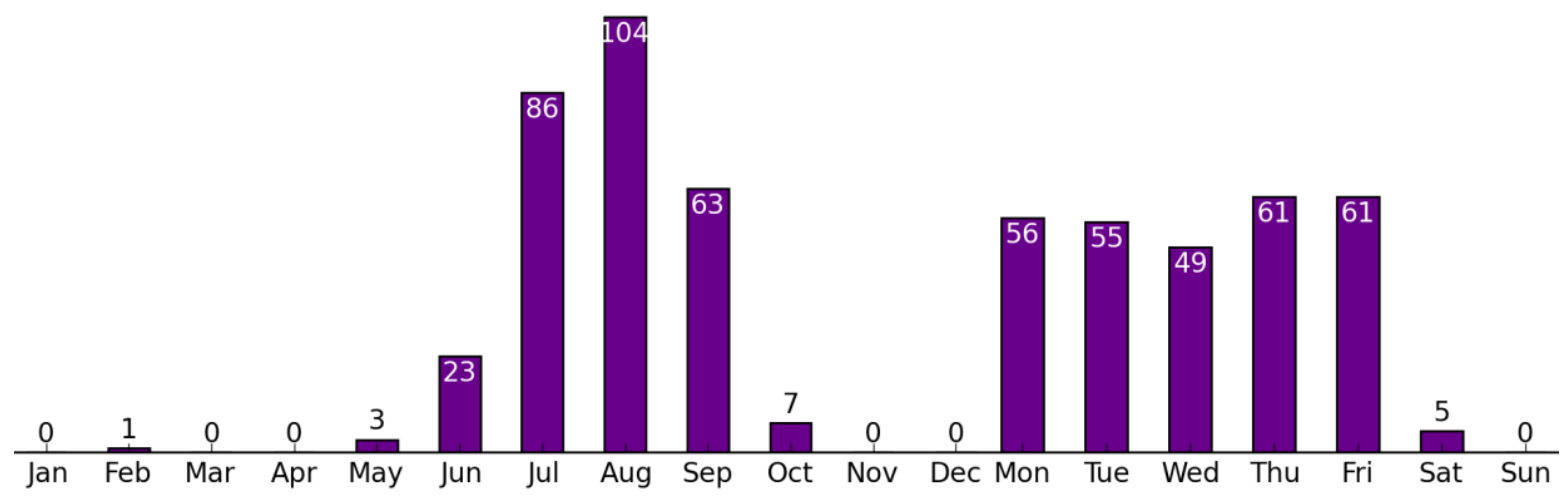

(a)

(b)

Figure 7. Numbers of historical events in CAISO (a) by month and (b) by weekday

\section{Modeling electric bills and GHG emissions under CPP 5.1 Electric bills}


We have previously modeled the electricity cost of manufacturing systems under the TOU rate in [62-65]. In this section, we model the annual electricity cost under the CPP rate. Tables 1 through 3 reveal that the CPP rate is essentially a TOU rate with extra terms. Therefore, this section utilizes our previous research work, and we only document the differences below.

For month $m(m=1,2, \ldots, 12)$ of a year, the total electric bill $c_{m}$ is the sum of all three components: the energy charge $c_{m, E}$, the demand charge $c_{m, D}$, and the customer or other charge $c_{m, O}$, i.e.,

$$
c_{m}=c_{m, E}+c_{m, D}+c_{m, O}
$$

The monthly customer charge $c_{m, O}$ is fixed and always known for a specific CPP program of a specific utility. For example, for the SCE TOU-GS-2 tariff in Table 2, $c_{m, O}=\$ 267.53 / \mathrm{month}$.

We assume the manufacturing system operates during weekdays only. There is no operation during weekends or holidays. The number of workdays and the number of CPP event days in month $m(m=1,2, \ldots, 12)$ are denoted by $w_{m}$ and $v_{m}$, respectively. For example, for the SCE TOU-GS-2 tariff, in August 2014, ten days fall in weekends and there are no federal holidays. So the number of workdays in that month is $w_{8}=21$ days. There are three event days $(8 / 4 / 2014$, $8 / 22 / 2014$, and 8/28/2014) based on Table A2. Therefore, $v_{8}=3$ days.

The demand of the manufacturing system is denoted by $d$. For example, suppose a manufacturing system contains four machines that each has a power of $25 \mathrm{~kW}$. Then, the combined system power demand is $d=100 \mathrm{~kW}$.

Let $h_{C R I}, h_{O N}, h_{M I D}$, and $h_{O F F}$ be the work hours during the critical-, on-, mid-, and off-peak periods, respectively, during a workday in month $m$. For example, for the SCE TOU-GS-2 tariff, on the event date 8/4/2014, if a production runs two 8-hour work shifts from 8:00 to 24:00, then based on the detailed information in Tables 2 and 3, $h_{C R I}=4$ hours (from 14:00 to 18:00), $h_{O N}=$ 6 hours (from 12:00 to 18:00), $h_{M I D}=9$ hours (from 8:00 to 12:00 and from 18:00 to 23:00), and $h_{O F F}=9$ hours (from 23:00 to 8:00 next day).

The energy use during the critical-, on-, mid-, and off-peak periods are equal to the power demand multiplied by corresponding time periods, i.e., $d \cdot h_{C R I}, d \cdot h_{O N}, d \cdot h_{M I D}$, and $d \cdot h_{O F F}$, respectively. Let $p_{m, O N, E}, p_{m, M I D, E}$, and $p_{m, O F F, E}$ be the energy prices during the on-, mid-, and offpeak periods, respectively, during a workday in month $m$. For example, for the SCE TOU-GS-2 tariff, on the event date 8/4/2014, based on the detailed information in Tables 2 and 3, $p_{m, O N, E},=$ $\$ 0.1457 / \mathrm{kWh}, p_{m, M I D, E}=\$ 0.09447 / \mathrm{kWh}$, and $p_{m, O F F, E}=\$ 0.06933 / \mathrm{kWh}$.

Let $p_{m, C R I, E}^{\text {adder }}$ be the energy charge adder during the critical-peak period of a CPP event day. For example, for the SCE TOU-GS-2 tariff, on the event date 8/4/2014, based on the detailed information in Tables 2 and 3, $p_{m, C R I, E}^{\text {adder }}=\$ 1.37453 / \mathrm{kWh}$.

Let $p_{m, O N, E}^{\text {credit }}, p_{m, M I D, E}^{\text {credit }}$, and $p_{m, O F F, E}^{\text {credit }}$ be the energy charge credits during the on-, mid-, and offpeak periods, respectively, during a workday in month $m$. For example, for the SCE TOU-GS-2 tariff, on the event date 8/4/2014, based on the detailed information in Tables 2 and $3, p_{m, O N, E}^{\text {credit }}=$ 
$p_{m, M I D, E}^{\text {credit }}=p_{m, O F F, E}^{\text {credit }}=\$ 0 / \mathrm{kWh}$ because this tariff involves only demand credit and no energy credit. For the PGE A-6 tariff, however, $p_{m, O N, E}^{\text {credit }}=\$ 0.10830 / \mathrm{kWh}, p_{m, M I D, E}^{\text {credit }}=\$ 0.02166$, and $p_{m, O F F, E}^{\text {credit }}=\$ 0 / \mathrm{kWh}$.

The monthly energy charge $c_{m, E}$ is the discounted TOU-based energy charge $c_{m, E}^{\text {disc }}$ plus the adder $c_{m, E}^{a d d e r}$ during CPP events, i.e.,

$$
c_{m, E}=c_{m, E}^{d i s c}+c_{m, E}^{a d d e r}
$$

where

$$
\begin{aligned}
c_{m, E}^{\text {disc }}=w_{m} \cdot & \cdot d h_{O N} \cdot\left(p_{m, O N, E}-p_{m, O N, E}^{c r e d i t}\right) \\
& +h_{M I D} \cdot\left(p_{m, M I D, E}-p_{m, M I D, E}^{c r d i t}\right) \\
& \left.+h_{O F F} \cdot\left(p_{m, O F F, E}-p_{m, O F F, E}^{c r e d i t}\right)\right]
\end{aligned}
$$

and

$$
c_{m, E}^{\text {adder }}=v_{m} \cdot d \cdot h_{C R I} \cdot p_{m, C R I, E}^{\text {adder }}
$$

Let $d_{O N}, d_{M I D}$, and $d_{O F F}$ be the maximum demands during any on-, mid-, and off-peak periods, respectively, in month $m$. For example, for the SCE TOU-GS-2 tariff, in August 2014, if a production system with $\mathrm{d}=100 \mathrm{~kW}$ runs one work shift from 8:00 to 16:00, then $d_{O N}=d_{M I D}=$ $100 \mathrm{~kW}$, and $d_{O F F}=0 \mathrm{~kW}$ because it does not involves off-peak hours (from 23:00 to 8:00 next day). Let $d_{B A S E}$ be the maximum base demand during any time period in month $m$. It is defined as

$$
d_{\text {BASE }}=\max \left(d_{\text {ON }}, d_{\text {MID }}, d_{\text {OFF }}\right)
$$

Let $p_{m, O N, D}, p_{m, M I D, D}$, and $p_{m, O F F, D}$ be the demand prices during on-, mid-, and off-peak periods, respectively, in month $m$. Let $p_{m, B A S E, D}$ be the base demand charge during any time period in month $m$. For example, for the SCE TOU-GS-2 tariff, on the event date 8/4/2014, based on the detailed information in Tables 2 and $3, p_{m, O N, D},=\$ 19.9 / \mathrm{kW}, p_{m, M I D, D}=\$ 5.82 / \mathrm{kW}, p_{m, O F F, D}=$ $\$ 0 / \mathrm{kW}$, and $p_{m, B A S E, D}=\$ 12.71 / \mathrm{kW}$.

Let $p_{m, O N, D}^{\text {credit }}, p_{m, M I D, D}^{\text {credit }}$, and $p_{m, O F F, D}^{\text {credit }}$ be the demand charge credits during the on-, mid-, and offpeak periods, respectively, during a workday in month $m$. For example, for the SCE TOU-GS-2 tariff, on the event date 8/4/2014, based on the detailed information in Tables 2 and $3, p_{m, O N, D}^{\text {credit }}=$ $\$ 10.75 / \mathrm{kW}$, and $p_{m, M I D, D}^{\text {credit }}=p_{m, O F F, D}^{\text {credit }}=\$ 0 / \mathrm{kW}$.

The monthly demand charge $c_{m, D}$ is the discounted TOU-based demand charge $c_{m, D}^{\text {disc }}$ plus the base demand charge $c_{m, D}^{\text {base }}$ during CPP events, i.e.,

$$
c_{m, D}=c_{m, D}^{\text {disc }}+c_{m, D}^{\text {base }}
$$

where 


$$
\begin{aligned}
c_{m, D}^{d i s c}= & d_{O N} \cdot\left(p_{m, O N, D}-p_{m, O N, D}^{c r e d i t}\right) \\
& +d_{M I D} \cdot\left(p_{m, M I D, D}-p_{m, O N, D}^{c r e d i t}\right) \\
& +d_{O F F} \cdot\left(p_{m, O F F, D}-p_{m, O N, D}^{\text {credit }}\right)
\end{aligned}
$$

and

$$
c_{m, D}^{\text {base }}=d_{B A S E} \cdot p_{m, B A S E, D}
$$

Therefore, the annual electric bill $c$ is rendered by adding up the bills from January to December of the year, i.e.,

$$
c=\sum_{m=1}^{12} c_{m}
$$

\subsection{GHG emissions}

Suppose a day is evenly discretized into 24 slots, with $t=1$ being the first slot, and $t=24$ being the last. The slot duration is equal to one hour. Let $s_{n, t}$ be the status of the manufacturing system during time slot $t$ in the $n$th day of a year. It is defined as

$$
s_{n, t}=\left\{\begin{array}{l}
1, \text { if the system is in production during time } t \\
0, \quad \text { otherwise }
\end{array}\right.
$$

For example, if a production runs two 8-hour work shifts on Monday, 9/8/2014 (which is the 251st day in 2014) from 8:00 to 24:00 midnight, then $s_{251, t}=1$ for $t=1,2, \ldots, 8$ and $s_{251, t}=1$ for $t=9,10, \ldots, 24$. The energy consumption (in $\mathrm{kWh}$ ) of the manufacturing system during the $t$ th hour $(t=1,2, \ldots, 24)$ of a day is

$$
e_{n, t}=s_{n, t} \cdot d \cdot 1=s_{n, t} \cdot d
$$

Studies have shown that GHG emission intensity for generating electricity also varies with time [75]. Let $r_{n, t}$ be the hourly GHG marginal emission rate (in $\mathrm{kg} / \mathrm{kWh}$ ) during time slot $t$ in the $n$th day of the year. For the $n$th day $(n=1,2, \ldots, 365)$ of a year, the total GHG emissions (in $\mathrm{kg}$ ) corresponding to the energy consumption is

$$
g_{n}=\sum_{t=1}^{24} r_{n, t} \cdot e_{n, t}
$$

Therefore, the annual GHG emissions (in $\mathrm{kg}$ ) is rendered by adding up the emissions from the first day to the last day of the year, i.e.,

$$
g=\sum_{n=1}^{\substack{\text { Num of days } \\ \text { in a year }}} g_{n}
$$

\section{Case studies}

In this section, we calculate the annual electric bill and GHG emissions of manufacturing systems under CPP and TOU rates listed in Section 3 with case studies. Then we examine the financial and environmental impacts when manufacturers switch among different production schedules and when they opt out from a default CPP to the corresponding TOU rate.

For each of the ten tariffs listed in Table 1, we consider six different scenarios listed in Table 5. For each scenario, we consider three different daily production schedules that are commonly 
adopted in manufacturing plants: one work shift ( 8 hours), two work shifts (16 hours), and three work shifts (24 hours). Under Scenario 1, the customer adopts the CPP rate and the production schedule starts at 8:00 in the morning. Scenario 2 differs from Scenario 1 in that the customer can reschedule the production within a certain time range so that one- and two-shift productions will never start earlier than 6:00 and never end later than 2:00 next day. Scenario 3 differs from Scenario 1 in that the customer can reschedule the production so it starts at any optimal time. Scenarios 4, 5, and 6 differ from Scenarios 1, 2, and 3, respectively, in that the customer opts out from CPP to the corresponding TOU rate. By rescheduling the starting time, the customer may take advantage of the lower prices during the off-peak period and avoid (or partially avoid) the electric use during the critical- or on-peak periods. Thus, the total electric bill can be lowered without affecting the total production. The best starting time for Scenarios 2, 3, 5, and 6 can be obtained by doing a quick one-time search with a step size of 15 minutes (same as the metering interval).

Table 5. Six different scenarios

\begin{tabular}{|l|l|l|}
\hline Scenario & Rate & Production shift start time \\
\hline CPP1 & CPP & 8:00 in the morning \\
\hline CPP2 & CPP & $\begin{array}{l}\text { Optimal starting time within the range: 1-shift (6:00 and 18:00); 2-shift (6:00 and 10:00); 3-shift } \\
\text { (any time) }\end{array}$ \\
\hline CPP3 & CPP & Optimal starting time (any time) \\
\hline TOU1 & TOU & 8:00 in the morning \\
\hline TOU2 & TOU & $\begin{array}{l}\text { Optimal starting time within the range: 1-shift (6:00 and 18:00); 2-shift (6:00 and 10:00); 3-shift } \\
\text { (any time) }\end{array}$ \\
\hline TOU3 & TOU & Optimal starting time (any time) \\
\hline
\end{tabular}

\subsection{Electric bill savings}

The values of the parameters used in Section 5 are all available in the tables in Sections 3 and 4. After applying Equations (1) through (9) for the six scenarios listed in Table 5, the results of the calculated electric bills are shown in Tables 6 and 7. The power demands of the manufacturing systems used in the case studies are also given in the table. These power demands are chosen in a way so that they all fall in the demand ranges of the examined tariffs listed in Table 1. Unlike TOU, which applies on a daily basis, the impact of the CPP rate depends on the number of events and the specific dates when these events are called, both of which are highly variable from year to year. Therefore, the multi-year long-term average impact is more meaningful than the impact of a single year. Thus, we calculate every value in Table 6 to represent the estimated average annual electricity bill of the manufacturing system during the ten-year record from 2005 to 2014, using currently effective rates.

The results in Tables 6 and 7 shows that the bill ramps up as the system power demand increases across different tariffs within the same utility. As the number of production shifts during a workday increases, the average annual bill will undoubtedly also increase. This is evidenced by comparing the one-shift bill values with the corresponding two-shift and three-shift values. In all the cases, the bills of the two- and three-shift production are approximately doubled and tripled, respectively, in comparison to that of the one-shift production.

Table 6. Average annual electric bills of the CPP scenarios

\begin{tabular}{|c|cc|c|c|c|c|c|c|c|c|c|}
\hline \multirow{2}{*}{ Utility } & Tariff & $\begin{array}{c}\text { System } \\
\text { Power } \\
(\mathrm{kW})\end{array}$ & 1-Shift Electric Bill (\$) & 2-Shift Electric Bill (\$) & \multicolumn{3}{|c|}{ 3-Shift Electric Bill (\$) } \\
\cline { 3 - 10 } & & CPP2 & CPP3 & CPP1 & CPP2 & CPP3 & CPP1 & CPP2 & CPP3 \\
\hline
\end{tabular}




\begin{tabular}{|c|c|c|c|c|c|c|c|c|c|c|c|}
\multirow{4}{*}{ PGE } & A-1 & 100 & 42,882 & 38,751 & 36,664 & 84,101 & 83,207 & 76,069 & 120,526 & 120,526 & 120,526 \\
\cline { 2 - 10 } & A-6 & 400 & 224,702 & 141,583 & 118,458 & 412,667 & 402,756 & 269,639 & 530,812 & 530,812 & 530,812 \\
\cline { 2 - 10 } & A-10 & 400 & 172,746 & 154,447 & 146,589 & 294,598 & 291,230 & 258,807 & 395,589 & 395,589 & 395,589 \\
\cline { 2 - 10 } & E-19 & 800 & $457,566304,111$ & 262,262 & 650,878 & 642,138 & 442,858 & 780,885 & 780,885 & 780,885 \\
\cline { 2 - 10 } & E-20 & 1200 & $605,280431,676$ & 383,945 & 881,266 & 869,758 & $632,6251,070,707$ & $1,070,707$ & $1,070,707$ \\
\hline \multirow{4}{*}{ SCE } & TOU-GS-1 & 15 & 6,040 & 5,064 & 4,790 & 11,517 & 11,385 & 9,659 & 15,981 & 15,981 & 15,981 \\
\cline { 2 - 10 } & TOU-GS-2 & 100 & 49,153 & 37,761 & 33,134 & 71,541 & 70,294 & 53,680 & 86,213 & 86,213 & 86,213 \\
\cline { 2 - 10 } & TOU-GS-3 & 400 & 199,861 & 154,737 & 136,233 & 285,885 & 281,105 & 214,869 & 341,237 & 341,237 & 341,237 \\
\cline { 2 - 10 } & TOU-8 & 1200 & $611,012452,469$ & 390,907 & 872,756 & 858,139 & 634,983 & $1,040,653$ & $1,040,653$ & $1,040,653$ \\
\hline SDGE & AL-TOU & 1200 & $692,087592,672$ & 504,249 & $1,021,222$ & $1,005,174$ & $823,2781,238,239$ & $1,238,239$ & $1,238,239$ \\
\hline
\end{tabular}

Table 7. Average annual electric bills of the TOU scenarios

\begin{tabular}{|c|c|c|c|c|c|c|c|c|c|c|c|}
\hline \multirow{2}{*}{ Utility } & \multirow{2}{*}{ Tariff } & \multirow{2}{*}{\begin{tabular}{|c} 
System \\
Power \\
$(\mathbf{k W})$
\end{tabular}} & \multicolumn{3}{|c|}{ 1-Shift Electric Bill (\$) } & \multicolumn{3}{|c|}{ 2-Shift Electric Bill (\$) } & \multicolumn{3}{|c|}{ 3-Shift Electric Bill (\$) } \\
\hline & & & TOU1 & TOU2 & TOU3 & TOU1 & TOU2 & TOU3 & TOU1 & TOU2 & TOU3 \\
\hline \multirow{5}{*}{ PGE } & & 100 & 42,595 & 39,747 & 37,661 & 83,526 & 82,632 & 78,063 & 120,947 & 120,947 & 120,947 \\
\hline & A-6 & 400 & 240,389 & 145,449 & 118,458 & 432,995 & 421,428 & 275,162 & 551,140 & 551,140 & 551,140 \\
\hline & A-10 & 400 & 174,147 & 163,552 & 155,693 & 291,158 & 287,790 & 270,775 & 395,013 & 395,013 & 395,013 \\
\hline & E-19 & 800 & 437,022 & 304,111 & 262,262 & 609,790 & 601,050 & 442,858 & 739,797 & 739,797 & 739,797 \\
\hline & E-20 & 1200 & 627,312 & 440,604 & 383,945 & 872,482 & 860,974 & 641,553 & $1,061,92$ & $1,061,92$ & $1,061,923$ \\
\hline \multirow{4}{*}{ SCE } & TOU-GS-1 & 15 & 5,931 & 5,449 & 5,176 & 11,299 & 11,167 & 10,430 & 16,148 & 16,148 & 16,148 \\
\hline & TOU-GS-2 & 100 & 50,154 & 37,761 & 33,134 & 69,243 & 67,996 & 53,680 & 83,915 & 83,915 & 83,915 \\
\hline & TOU-GS-3 & 400 & 204,969 & 154,737 & 136,233 & 277,798 & 273,018 & 214,869 & 333,150 & 333,150 & 333,150 \\
\hline & TOU-8 & 1200 & 628,689 & 452,469 & 390,907 & 850,847 & 836,230 & 634,983 & $1,018,74$ & $1,018,74$ & $1,018,745$ \\
\hline SDGE & AL-TOU & 1200 & 728,332 & 592,672 & 504,249 & $1,039,421$ & $1,023,373$ & 82327 & 12564 & & $1,256,439$ \\
\hline
\end{tabular}

To more intuitively show the differences among the bills under the six scenarios for each tariff, we also calculated the savings on the average annual electricity bills by switching from one scenario to another and listed the results in Tables 8 through 10. Careful observation of the numbers suggests that:

(i) Table 8 shows the comparison results for one-shift production. We first examine the switch $\mathrm{CPP} 1 \rightarrow \mathrm{CPP} 2$. it represents that the customer reschedule production so that the starting time is changed from 8:00 to the best time within a certain range that will lead to the lowest electric bill, while keeping enrolled in the default CPP. The best start time is 18:00 for PGE, SCE, and SDGE tariffs. All ten cases in Table 8 show positive values and the average is over $22 \%$, which translate into significant savings ranging from several thousand to several hundred thousand dollars. The average annual saving of the switch is $\$ 74,806$.

(ii) Then we examine the switch $\mathrm{CPP} 1 \rightarrow \mathrm{CPP} 3$ in Table 8 . The switch represents that the customer reschedule production so the starting time is changed from 8:00 to the best time that will lead to the lowest electric bill, while keeping enrolled in the default CPP. The best start time is 23:00 for both PGE and SCE tariffs, and it is 22:00 for the SDGE tariff. All ten cases in Table 8 show positive values and the average is over $30 \%$. The average annual saving of the switch is $\$ 104,410$. 
(iii) The switch $\mathrm{CPP} 1 \rightarrow \mathrm{TOU} 1$ in Table 8 represents that the customer opts out from the default CPP to the TOU rate, while keeping production from 8:00 to 16:00 unchanged. The average saving is negative, which means the customer will actually suffer from economic losses by conducting such a switch, assuming no production rescheduling. Similar results are also observed for the switches with production rescheduling, i.e., $\mathrm{CPP} 2 \rightarrow \mathrm{TOU} 2$ and $\mathrm{CPP} 3 \rightarrow \mathrm{TOU} 3$.

(iv) For two-shift production, Table 9 shows that both $\mathrm{CPP} 1 \rightarrow \mathrm{CPP} 2$ and $\mathrm{CPP} 1 \rightarrow \mathrm{CPP} 3$ can still achieve positive savings, although the saving magnitudes are smaller than in Table 8. This is because 2-shift production will run 16 hours per day, which leave less flexibility for production rescheduling to take advantage of the lower prices during offpeak periods. Unlike in Table 8 , the switches CPP1 $\rightarrow$ TOU1 and CPP2 $\rightarrow$ TOU2 will result in positive average savings, and the switch $\mathrm{CPP} 3 \rightarrow \mathrm{TOU} 3$ will result in a negative average saving.

(v) For three-shift production, the pattern in Table 10 is quite different from that of Table 8. The switches $\mathrm{CPP} 1 \rightarrow \mathrm{CPP} 2$ and $\mathrm{CPP} 1 \rightarrow \mathrm{CPP} 3$ have no impact on the total bill, and the savings of all ten cases are $0 \%$. This is because the business process has no flexibility since the production has to run 24 hours a day. The electric bill is fixed no matter when the starting time is. For the same reason, the switches CPP1 $\rightarrow$ TOU1, CPP2 $\rightarrow$ TOU2, and $\mathrm{CPP} 3 \rightarrow \mathrm{TOU} 3$ result in exactly same values for all ten cases, and the average savings are all positive.

(vi) To sum up, the customers who run one- or two-shift productions can significantly lower their electric bills in the default CPP programs by adjusting their production schedules. Whether the customer should keep enrolled in the CPP or opt out to the TOU should be decided on a case-by-case basis, and it is usually irrelevant to when the production starts.

Table 8. Savings (in \%) on the average annual electric bills for one-shift production by switching between scenarios

\begin{tabular}{|c|c|c|c|c|c|c|}
\hline \multirow{2}{*}{ Utility } & \multirow{2}{*}{ Tariff } & \multicolumn{5}{|c|}{ 1-Shift Electric Bill Saving (\%) } \\
\hline & & $\mathrm{CPP} 1 \rightarrow \mathrm{CPP} 2$ & $\mathrm{CPP} 1 \rightarrow \mathrm{CPP3}$ & $\mathrm{CPP} 1 \rightarrow$ TOU 1 & $\mathrm{CPP} 2 \rightarrow \mathrm{TOU} 2$ & $\mathrm{CPP} 3 \rightarrow \mathrm{TOU} 3$ \\
\hline \multirow{5}{*}{ PGE } & A-1 & 9.63 & 14.50 & 0.67 & -2.57 & -2.72 \\
\hline & A-6 & 36.99 & 47.28 & -6.98 & -2.73 & 0.00 \\
\hline & A-10 & 10.59 & 15.14 & -0.81 & -5.89 & -6.21 \\
\hline & E-19 & 33.54 & 42.68 & 4.49 & 0.00 & 0.00 \\
\hline & E-20 & 28.68 & 36.57 & -3.64 & -2.07 & 0.00 \\
\hline \multirow{4}{*}{ SCE } & TOU-GS-1 & 16.17 & 20.69 & 1.81 & -7.62 & -8.05 \\
\hline & TOU-GS-2 & 23.18 & 32.59 & -2.04 & 0.00 & 0.00 \\
\hline & TOU-GS-3 & 22.58 & 31.84 & -2.56 & 0.00 & 0.00 \\
\hline & TOU-8 & 25.95 & 36.02 & -2.89 & 0.00 & 0.00 \\
\hline SDGE & AL-TOU & 14.36 & 27.14 & -5.24 & 0.00 & 0.00 \\
\hline \multicolumn{2}{|c|}{ mean } & 22.17 & 30.45 & -1.72 & -2.09 & -1.70 \\
\hline
\end{tabular}

Table 9. Savings (in \%) on the average annual electric bills for two-shift production by switching between scenarios

\begin{tabular}{|c|c|c|c|c|c|c|}
\hline \multirow{2}{*}{ Utility } & \multirow{2}{*}{ Tariff } & \multicolumn{5}{|c|}{ 2-Shift Electric Bill Saving (\%) } \\
\cline { 3 - 7 } & & $\mathbf{C P P 1} \rightarrow \mathbf{C P P 2}$ & $\mathbf{C P P 1} \rightarrow \mathbf{C P P 3}$ & $\mathbf{C P P 1} \rightarrow$ TOU1 & $\mathbf{C P P 2} \rightarrow$ TOU2 & CPP3 $\rightarrow$ TOU3 \\
\hline \multirow{2}{*}{ PGE } & A-1 & 1.06 & 9.55 & 0.68 & 0.69 & -2.62 \\
\cline { 2 - 7 }
\end{tabular}




\begin{tabular}{|c|c|c|c|c|c|c|}
\hline & A- 6 & 2.40 & 34.66 & -4.93 & -4.64 & -2.05 \\
\hline & A-10 & 1.14 & 12.15 & 1.17 & 1.18 & -4.62 \\
\hline & E-19 & 1.34 & 31.96 & 6.31 & 6.40 & 0.00 \\
\hline & E-20 & 1.31 & 28.21 & 1.00 & 1.01 & -1.41 \\
\hline \multirow{4}{*}{ SCE } & TOU-GS-1 & 1.15 & 16.13 & 1.90 & 1.92 & -7.98 \\
\hline & TOU-GS-2 & 1.74 & 24.97 & 3.21 & 3.27 & 0.00 \\
\hline & TOU-GS-3 & 1.67 & 24.84 & 2.83 & 2.88 & 0.00 \\
\hline & TOU-8 & 1.67 & 27.24 & 2.51 & 2.55 & 0.00 \\
\hline SDGE & AL-TOU & 1.57 & 19.38 & -1.78 & -1.81 & 0.00 \\
\hline \multicolumn{2}{|c|}{ mean } & 1.51 & 22.91 & 1.29 & 1.35 & -1.87 \\
\hline
\end{tabular}

Table 10. Savings (in \%) on the average annual electric bills for three-shift production by switching between scenarios

\begin{tabular}{|c|c|c|c|c|c|c|}
\hline \multirow{2}{*}{ Utility } & \multirow{2}{*}{ Tariff } & \multicolumn{5}{|c|}{ 3-Shift Electric Bill Saving (\%) } \\
\hline & & $\mathrm{CPP} 1 \rightarrow \mathrm{CPP} 2$ & $\mathrm{CPP} 1 \rightarrow \mathrm{CPP3}$ & $\mathrm{CPP} 1 \rightarrow \mathrm{TOU} 1$ & $\mathrm{CPP} 2 \rightarrow \mathrm{TOU} 2$ & $\mathrm{CPP} 3 \rightarrow \mathrm{TOU} 3$ \\
\hline \multirow{5}{*}{ PGE } & A-1 & 0.00 & 0.00 & -0.35 & -0.35 & -0.35 \\
\hline & A-6 & 0.00 & 0.00 & -3.83 & -3.83 & -3.83 \\
\hline & A-10 & 0.00 & 0.00 & 0.15 & 0.15 & 0.15 \\
\hline & E-19 & 0.00 & 0.00 & 5.26 & 5.26 & 5.26 \\
\hline & E-20 & 0.00 & 0.00 & 0.82 & 0.82 & 0.82 \\
\hline \multirow{4}{*}{ SCE } & TOU-GS-1 & 0.00 & 0.00 & -1.05 & -1.05 & -1.05 \\
\hline & TOU-GS-2 & 0.00 & 0.00 & 2.67 & 2.67 & 2.67 \\
\hline & TOU-GS-3 & 0.00 & 0.00 & 2.37 & 2.37 & 2.37 \\
\hline & TOU-8 & 0.00 & 0.00 & 2.11 & 2.11 & 2.11 \\
\hline SDGE & AL-TOU & 0.00 & 0.00 & -1.47 & -1.47 & -1.47 \\
\hline \multicolumn{2}{|c|}{ mean } & 0.00 & 0.00 & 0.67 & 0.67 & 0.67 \\
\hline
\end{tabular}

\subsection{GHG emissions reduction}

The hourly GHG emissions rate $r_{n, t}$ that measures carbon intensity of electricity on the California grid can be derived from an electricity generation dispatch model called PLEXOS [76]. As an example, the hourly marginal emissions rates in 2008 are shown in Figure 8. Detailed information of nearly all generators in the Western Electricity Coordinating Council (WECC) as well as the transmission paths are integrated in PLEXOS. The PLEXOS software is licensed by the CAISO and commonly used in California for modeling market redesign and technology upgrade efforts. 


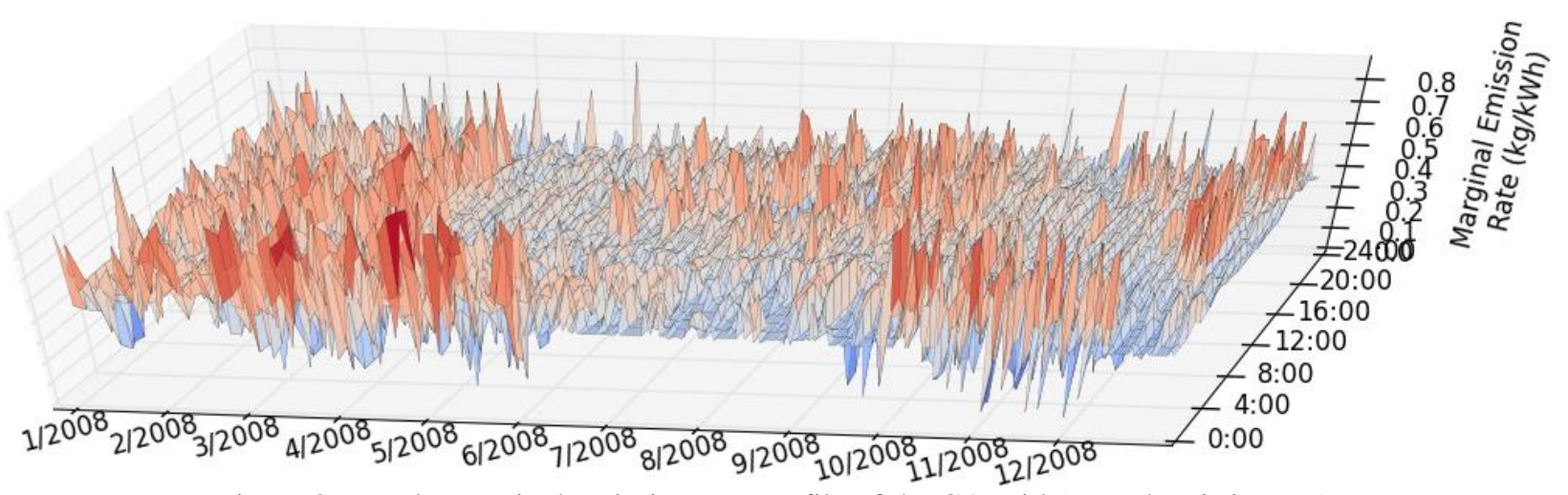

Figure 8. Hourly marginal emission rate profile of the CA grid (Raw data is in [76])

After the schedules have been determined in Section 5.1 and the electric bills are calculated, we apply Equations (10) through (13) for the six scenarios listed in Table 5 to obtain the associated GHG emissions. The results of the average annual GHG emissions of the CPP scenarios are shown in Table 11. The average annual GHG emissions of the TOU scenarios are exactly the same as in the corresponding CPP scenarios. This is because the GHG emissions are only determined by the production schedule and system power, and they have nothing to do with the differences in the pricing information in Tables 2 and 3. Therefore, the switches CPP1 $\rightarrow$ TOU1, $\mathrm{CPP} 2 \rightarrow \mathrm{TOU} 2$, and CPP3 $\rightarrow$ TOU3 will not lead to any changes in GHG emissions.

Table 11. Average annual GHG emissions of the CPP scenarios

\begin{tabular}{|c|c|c|c|c|c|c|c|c|c|c|c|}
\hline \multirow[b]{2}{*}{ Utility } & \multirow[b]{2}{*}{ Tariff } & \multirow{2}{*}{$\begin{array}{c}\text { System } \\
\text { Power } \\
\text { (kW) }\end{array}$} & \multicolumn{3}{|c|}{ 1-Shift GHG Emissions (kg) } & \multicolumn{3}{|c|}{ 2-Shift GHG Emissions (kg) } & \multicolumn{3}{|c|}{ 3-Shift GHG Emissions (kg) } \\
\hline & & & CPP1 & CPP2 & CPP3 & CPP1 & CPP2 & CPP3 & CPP1 & CPP2 & CPP3 \\
\hline \multirow{5}{*}{ PGE } & & 100 & & & & & & & & & \\
\hline & & & & & & & & & & & \\
\hline & & & & & & & & & & & \\
\hline & & & 751 , & 726, & & 1,49 & $1,485,716$ & 1,44 & 2,20 & & \\
\hline & & & & & & & & & & & \\
\hline \multirow{4}{*}{ SCE } & & & & & & & & & & & \\
\hline & TOU- & 100 & & 90,8 & & & 185,714 & & 275,585 & 275,585 & 275,585 \\
\hline & TOU-GS-3 & 400 & 375,869 & 363,339 & 354,707 & 745,320 & 742,858 & 722,649 & $1,102,338$ & $1,102,338$ & $1,102,338$ \\
\hline & & 1200 & & & & & & & & & \\
\hline & & & & & & & & & & & \\
\hline
\end{tabular}

To show the differences among the bills under the three CPP scenarios for each tariff, we calculated the reductions on the average annual GHG emissions by switching from one scenario to another in Tables 12 and 13. Careful observation of the numbers suggests that:

(i) Table 12 shows the comparison results for one-shift production. We first examine the switch CPP1 $\rightarrow$ CPP2. All ten cases in Table 12 show positive values and the average is $3.33 \%$, which is equivalent to an average annual GHG emissions reduction of $18,216.20$ $\mathrm{kg}$. For the switch CPP1 $\rightarrow \mathrm{CPP} 3$, higher GHG emissions reduction can be achieved. The average is $5.63 \%$, or $30,757.71 \mathrm{~kg}$.

(ii) For two-shift production, Table 13 shows that both $\mathrm{CPP} 1 \rightarrow \mathrm{CPP} 2$ and $\mathrm{CPP} 1 \rightarrow \mathrm{CPP} 3$ can still achieve positive GHG emissions reductions, although with smaller margins, i.e., $0.33 \%$ and $3.03 \%$, respectively. 
(iii) For three-shift production, the switches $\mathrm{CPP} 1 \rightarrow \mathrm{CPP} 2$ and $\mathrm{CPP} 1 \rightarrow \mathrm{CPP} 3$ have no impact on the GHG emissions and the reductions for all ten cases are $0 \%$. The reason is similar to the unchanged electric bills.

(vi) Combining the findings in Section 5.1, we conclude that the customers who run one- or two-shift productions can both lower their electric bills and contribute to the GHG emissions reduction in the default CPP programs by properly adjusting their production schedules.

Table 12. Average annual GHG emissions reductions (in \%) for one-shift production by switching between CPP scenarios

\begin{tabular}{|c|c|c|c|c|c|}
\hline \multirow{2}{*}{ Utility } & \multirow{2}{*}{ Tariff } & \multicolumn{2}{|c|}{ 1-Shift GHG Reduction (\%) } & \multicolumn{2}{|c|}{ 1-Shift GHG Reduction (kg) } \\
\hline & & $\mathrm{CPP} 1 \rightarrow \mathrm{CPP} 2$ & $\mathrm{CPP} 1 \rightarrow \mathrm{CPP} 3$ & $\mathrm{CPP} 1 \rightarrow \mathrm{CPP} 2$ & $\mathrm{CPP} 1 \rightarrow \mathrm{CPP} 3$ \\
\hline \multirow{5}{*}{ PGE } & A-1 & 3.33 & 5.63 & 3132.62 & 5290.55 \\
\hline & A-6 & 3.33 & 5.63 & 12530.49 & 21162.19 \\
\hline & A-10 & 3.33 & 5.63 & 12530.49 & 21162.19 \\
\hline & E-19 & 3.33 & 5.63 & 25060.98 & 42324.38 \\
\hline & E-20 & 3.33 & 5.63 & 37591.47 & 63486.58 \\
\hline \multirow{4}{*}{ SCE } & TOU-GS-1 & 3.33 & 5.63 & 469.89 & 793.58 \\
\hline & TOU-GS-2 & 3.33 & 5.63 & 3132.62 & 5290.55 \\
\hline & TOU-GS-3 & 3.33 & 5.63 & 12530.49 & 21162.19 \\
\hline & TOU-8 & 3.33 & 5.63 & 37591.47 & 63486.58 \\
\hline SDGE & AL-TOU & 3.33 & 5.62 & 37591.47 & 63418.28 \\
\hline \multicolumn{2}{|c|}{ mean } & 3.33 & 5.63 & 18216.20 & 30757.71 \\
\hline
\end{tabular}

Table 13. Average annual GHG emissions reductions (in \%) for two-shift production by switching between CPP scenarios

\begin{tabular}{|c|c|c|c|c|c|}
\hline \multirow{2}{*}{ Utility } & \multirow{2}{*}{ Tariff } & \multicolumn{2}{|c|}{ 2-Shift GHG Reduction (\%) } & \multicolumn{2}{|c|}{ 2-Shift GHG Reduction (kg) } \\
\hline & & $\mathrm{CPP} 1 \rightarrow \mathrm{CPP} 2$ & $\mathrm{CPP} 1 \rightarrow \mathrm{CPP} 3$ & $\mathrm{CPP} 1 \rightarrow \mathrm{CPP} 2$ & $\mathrm{CPP} 1 \rightarrow \mathrm{CPP} 3$ \\
\hline \multirow{5}{*}{ PGE } & A-1 & 0.33 & 3.02 & 615.61 & 5625.38 \\
\hline & A-6 & 0.33 & 3.03 & 2462.44 & 22580.55 \\
\hline & A-10 & 0.33 & 3.04 & 2462.44 & 22671.38 \\
\hline & E-19 & 0.33 & 3.04 & 4924.89 & 45342.76 \\
\hline & E-20 & 0.33 & 3.04 & 7387.33 & 68014.14 \\
\hline \multirow{4}{*}{ SCE } & TOU-GS-1 & 0.33 & 3.04 & 92.34 & 850.18 \\
\hline & TOU-GS-2 & 0.33 & 3.04 & 615.61 & 5667.85 \\
\hline & TOU-GS-3 & 0.33 & 3.04 & 2462.44 & 22671.38 \\
\hline & TOU-8 & 0.33 & 3.02 & 7387.33 & 67504.56 \\
\hline SDGE & AL-TOU & 0.33 & 3.02 & 7387.33 & 67469.14 \\
\hline \multicolumn{2}{|c|}{ mean } & 0.33 & 3.03 & 3579.78 & 32839.73 \\
\hline
\end{tabular}

\section{Conclusions}

In this paper, we have performed a detailed analysis of CPP, a demand response technology that has the potential to lower energy cost for customers and reduce the need for more GHG emitting 
power plants. Case studies in California have been used to illustrate how to choose between CPP and TOU electric rates for manufacturing applications, when both options are available to industrial customers. However, the insights gained in this paper are also meaningful for industrial customers that are currently enrolled or considering enrolling in CPP in other states or countries.

Based on the theoretical development and the case studies in this paper, we conclude that:

(i) Whether a manufacturing customer will experience a saving or a loss on the average annual electric bill when choosing one rate over the other depends on whether they have the flexibility to shift production so the electric use during the high-cost periods can be at least partially avoided.

(ii) The case studies reveal that the lowest electric bill for industrial customers with oneand two-shift productions will be achieved under the CPP rate with proper rescheduling of the production to avoid such high-cost periods. In addition to the financial savings due to the rescheduling actions, significant environmental benefits such as reduced GHG emissions associated with the avoided demand during peak hours can also be achieved. The savings on the annual electric bill can be $30.45 \%$ with a simultaneous GHG emissions reduction of $5.63 \%$ for an average industrial customer.

(iii) The average annual electric bill or GHG emissions cannot be lowered for industrial customers requiring three-shift operation through rescheduling the whole block of production. Whether the customer should keep enrolled in the CPP or opt out to the TOU should be decided on a case-by-case basis. Under such circumstances, intelligent scheduling strategies that involve more detailed adjustments of the sequences of individual processes may be required, and the utilization of buffers between processes to create additional production flexibility may be needed. Some of our initial work has been done in this area using particle swarm optimization and just-for-peak buffers [63, 77], the methods established has been applied to manufacturing applications under the TOU rate. Extending these methods from TOU to CPP will be conducted in a future work.

(iv) Although the results presented in Section 6 are limited to the specific programs examined, the proposed approach in Section 5 is a general one. For different CPP and TOU rate details, the approach can be followed to achieve the solutions on a case-bycase basis. With the calculated results, manufacturing enterprises will be able to make more informed decisions on which service to choose and how to use electricity while fulfilling their role for sustainability by enrolling.

\section{Acknowledgements}

This work is supported by the U.S. National Science Foundation under Grant Number 1131537. All the figures in this paper are generated using Python and Matplotlib.

\section{Appendix A}

Table A1. Historical CPP event dates of PGE (Raw data is in [72, 73])

\begin{tabular}{|ccccccccc|c|}
\hline $\mathbf{2 0 0 5}$ & $\mathbf{2 0 0 6}$ & $\mathbf{2 0 0 7}$ & $\mathbf{2 0 0 8}$ & $\mathbf{2 0 0 9}$ & $\mathbf{2 0 1 0}$ & $\mathbf{2 0 1 1}$ & $\mathbf{2 0 1 2}$ & $\mathbf{2 0 1 3}$ & $\mathbf{2 0 1 4}$ \\
\hline $7 / 1 / 2005$ & $6 / 21 / 2006$ & $6 / 13 / 2007$ & $5 / 15 / 2008$ & $6 / 29 / 2009$ & $7 / 16 / 2010$ & $6 / 21 / 2011$ & $7 / 9 / 2012$ & $6 / 7 / 2013$ & $6 / 9 / 2014$ \\
$7 / 12 / 2005$ & $6 / 22 / 2006$ & $7 / 3 / 2007$ & $5 / 16 / 2008$ & $6 / 30 / 2009$ & $8 / 16 / 2010$ & $7 / 5 / 2011$ & $7 / 10 / 2012$ & $6 / 28 / 2013$ & $6 / 30 / 2014$ \\
$7 / 13 / 2005$ & $6 / 23 / 2006$ & $7 / 5 / 2007$ & $6 / 20 / 2008$ & $7 / 13 / 2009$ & $8 / 23 / 2010$ & $7 / 29 / 2011$ & $7 / 11 / 2012$ & $7 / 1 / 2013$ & $7 / 1 / 2014$
\end{tabular}




\begin{tabular}{|ccccccccc|c|}
$7 / 14 / 2005$ & $6 / 26 / 2006$ & $7 / 6 / 2007$ & $7 / 7 / 2008$ & $7 / 14 / 2009$ & $8 / 24 / 2010$ & $8 / 23 / 2011$ & $7 / 12 / 2012$ & $7 / 2 / 2013$ & $7 / 7 / 2014$ \\
$7 / 15 / 2005$ & $7 / 17 / 2006$ & $7 / 9 / 2007$ & $7 / 8 / 2008$ & $7 / 16 / 2009$ & $8 / 25 / 2010$ & $8 / 29 / 2011$ & $8 / 2 / 2012$ & $7 / 9 / 2013$ & $7 / 14 / 2014$ \\
$7 / 18 / 2005$ & $7 / 18 / 2006$ & $8 / 1 / 2007$ & $7 / 9 / 2008$ & $7 / 21 / 2009$ & $9 / 1 / 2010$ & $9 / 2 / 2011$ & $8 / 8 / 2012$ & $7 / 19 / 2013$ & $7 / 25 / 2014$ \\
$8 / 5 / 2005$ & $7 / 20 / 2006$ & $8 / 21 / 2007$ & $8 / 14 / 2008$ & $7 / 27 / 2009$ & $9 / 2 / 2010$ & $9 / 6 / 2011$ & $8 / 9 / 2012$ & $9 / 9 / 2013$ & $7 / 28 / 2014$ \\
$8 / 8 / 2005$ & $7 / 21 / 2006$ & $8 / 22 / 2007$ & $8 / 27 / 2008$ & $8 / 10 / 2009$ & $9 / 3 / 2010$ & $9 / 7 / 2011$ & $8 / 10 / 2012$ & $9 / 10 / 2013$ & $7 / 29 / 2014$ \\
$9 / 29 / 2005$ & $7 / 24 / 2006$ & $8 / 28 / 2007$ & $8 / 28 / 2008$ & $8 / 11 / 2009$ & $9 / 28 / 2010$ & $9 / 20 / 2011$ & $8 / 13 / 2012$ & $10 / 18 / 2013$ & $7 / 31 / 2014$ \\
& $7 / 25 / 2006$ & $8 / 29 / 2007$ & $8 / 29 / 2008$ & $8 / 18 / 2009$ & & & $10 / 1 / 2012$ & & $9 / 12 / 2014$ \\
& $7 / 26 / 2006$ & $8 / 30 / 2007$ & $9 / 4 / 2008$ & $8 / 27 / 2009$ & & & $10 / 2 / 2012$ & \\
& $8 / 9 / 2006$ & $8 / 31 / 2007$ & & $8 / 28 / 2009$ & & & & & \\
& $8 / 31 / 2006$ & & & & & & & & \\
$9 / 1 / 2006$ & & & & & & & & \\
$9 / 22 / 2006$ & & & & & & & & \\
\hline
\end{tabular}

Table A2. Historical CPP event dates of SCE (Raw data is in [72, 73])

\begin{tabular}{|ccccccccc|c|}
\hline $\mathbf{2 0 0 5}$ & $\mathbf{2 0 0 6}$ & $\mathbf{2 0 0 7}$ & $\mathbf{2 0 0 8}$ & $\mathbf{2 0 0 9}$ & $\mathbf{2 0 1 0}$ & $\mathbf{2 0 1 1}$ & $\mathbf{2 0 1 2}$ & $\mathbf{2 0 1 3}$ & $\mathbf{2 0 1 4}$ \\
\hline $7 / 21 / 2005$ & $6 / 29 / 2006$ & $6 / 7 / 2007$ & $7 / 9 / 2008$ & $6 / 18 / 2009$ & $6 / 30 / 2010$ & $6 / 21 / 2011$ & $6 / 29 / 2012$ & $7 / 1 / 2013$ & $7 / 8 / 2014$ \\
$7 / 22 / 2005$ & $7 / 10 / 2006$ & $6 / 22 / 2007$ & $7 / 10 / 2008$ & $7 / 15 / 2009$ & $7 / 16 / 2010$ & $7 / 5 / 2011$ & $7 / 12 / 2012$ & $7 / 3 / 2013$ & $7 / 14 / 2014$ \\
$7 / 25 / 2005$ & $7 / 13 / 2006$ & $7 / 3 / 2007$ & $7 / 21 / 2008$ & $7 / 17 / 2009$ & $8 / 6 / 2010$ & $7 / 19 / 2011$ & $7 / 23 / 2012$ & $8 / 21 / 2013$ & $7 / 30 / 2014$ \\
$8 / 26 / 2005$ & $7 / 14 / 2006$ & $7 / 5 / 2007$ & $8 / 1 / 2008$ & $7 / 20 / 2009$ & $8 / 12 / 2010$ & $8 / 1 / 2011$ & $8 / 7 / 2012$ & $8 / 28 / 2013$ & $8 / 4 / 2014$ \\
$8 / 29 / 2005$ & $7 / 17 / 2006$ & $7 / 6 / 2007$ & $8 / 5 / 2008$ & $7 / 22 / 2009$ & $8 / 16 / 2010$ & $8 / 3 / 2011$ & $8 / 9 / 2012$ & $8 / 30 / 2013$ & $8 / 22 / 2014$ \\
$8 / 30 / 2005$ & $7 / 19 / 2006$ & $8 / 15 / 2007$ & $8 / 6 / 2008$ & $7 / 27 / 2009$ & $8 / 18 / 2010$ & $8 / 12 / 2011$ & $8 / 13 / 2012$ & $9 / 4 / 2013$ & $8 / 28 / 2014$ \\
$8 / 31 / 2005$ & $7 / 25 / 2006$ & $8 / 16 / 2007$ & $8 / 11 / 2008$ & $7 / 28 / 2009$ & $8 / 23 / 2010$ & $8 / 16 / 2011$ & $8 / 20 / 2012$ & $9 / 6 / 2013$ & $9 / 8 / 2014$ \\
$9 / 15 / 2005$ & $7 / 26 / 2006$ & $8 / 17 / 2007$ & $8 / 12 / 2008$ & $8 / 20 / 2009$ & $8 / 24 / 2010$ & $8 / 18 / 2011$ & $8 / 27 / 2012$ & $9 / 19 / 2013$ & $9 / 11 / 2014$ \\
$9 / 20 / 2005$ & $7 / 27 / 2006$ & $8 / 21 / 2007$ & $8 / 27 / 2008$ & $8 / 27 / 2009$ & $8 / 25 / 2010$ & $8 / 23 / 2011$ & $8 / 29 / 2012$ & $9 / 23 / 2013$ & $9 / 15 / 2014$ \\
$9 / 22 / 2005$ & $8 / 23 / 2006$ & $8 / 29 / 2007$ & $8 / 28 / 2008$ & $8 / 28 / 2009$ & $9 / 2 / 2010$ & $8 / 26 / 2011$ & $9 / 10 / 2012$ & $9 / 30 / 2013$ & $9 / 16 / 2014$ \\
$9 / 28 / 2005$ & $8 / 24 / 2006$ & $8 / 30 / 2007$ & $8 / 29 / 2008$ & $9 / 1 / 2009$ & $9 / 20 / 2010$ & $9 / 6 / 2011$ & $9 / 20 / 2012$ & $10 / 4 / 2013$ & $9 / 22 / 2014$ \\
$9 / 29 / 2005$ & $8 / 25 / 2006$ & $8 / 31 / 2007$ & $9 / 3 / 2008$ & $9 / 2 / 2009$ & $9 / 27 / 2010$ & $9 / 23 / 2011$ & $9 / 28 / 2012$ & $10 / 17 / 2013$ & $9 / 23 / 2014$ \\
\hline
\end{tabular}

Table A3. Historical CPP event dates of SDGE (Raw data is in $[72,73]$ )

\begin{tabular}{|ccccccccc|c|}
\hline $\mathbf{2 0 0 5}$ & $\mathbf{2 0 0 6}$ & $\mathbf{2 0 0 7}$ & $\mathbf{2 0 0 8}$ & $\mathbf{2 0 0 9}$ & $\mathbf{2 0 1 0}$ & $\mathbf{2 0 1 1}$ & $\mathbf{2 0 1 2}$ & $\mathbf{2 0 1 3}$ & $\mathbf{2 0 1 4}$ \\
\hline $7 / 21 / 2005$ & $6 / 27 / 2006$ & $8 / 15 / 2007$ & None & $8 / 27 / 2009$ & $8 / 25 / 2010$ & $8 / 27 / 2011$ & $8 / 9 / 2012$ & $8 / 29 / 2013$ & $2 / 7 / 2014$ \\
$7 / 22 / 2005$ & $6 / 29 / 2006$ & $8 / 16 / 2007$ & & $8 / 28 / 2009$ & $8 / 26 / 2010$ & $9 / 7 / 2011$ & $8 / 11 / 2012$ & $9 / 4 / 2013$ & $5 / 15 / 2014$ \\
$8 / 26 / 2005$ & $6 / 30 / 2006$ & $8 / 17 / 2007$ & & $8 / 29 / 2009$ & $9 / 27 / 2010$ & & $8 / 13 / 2012$ & $9 / 5 / 2013$ & $7 / 31 / 2014$ \\
$9 / 29 / 2005$ & $7 / 12 / 2006$ & $8 / 21 / 2007$ & & $8 / 31 / 2009$ & $9 / 28 / 2010$ & & $8 / 14 / 2012$ & $9 / 6 / 2013$ & $9 / 15 / 2014$ \\
$9 / 30 / 2005$ & $7 / 13 / 2006$ & $8 / 29 / 2007$ & & $9 / 3 / 2009$ & & & $8 / 21 / 2012$ & & $9 / 16 / 2014$ \\
& $7 / 14 / 2006$ & $8 / 30 / 2007$ & & $9 / 4 / 2009$ & & & $8 / 30 / 2012$ & & $9 / 17 / 2014$ \\
& $7 / 18 / 2006$ & $8 / 31 / 2007$ & $9 / 24 / 2009$ & & & $9 / 14 / 2012$ & & \\
& $7 / 21 / 2006$ & $9 / 3 / 2007$ & $9 / 25 / 2009$ & & & $9 / 15 / 2012$ & & \\
& $7 / 22 / 2006$ & $9 / 4 / 2007$ & & & & & $10 / 2 / 2012$ & & \\
& $7 / 24 / 2006$ & $9 / 5 / 2007$ & & & & & & & \\
& $9 / 6 / 2006$ & $10 / 24 / 2007$ & & & & & & & \\
\hline
\end{tabular}

Table A4. Observed federal holidays (Raw data is in [74])

(Note that if a holiday falls during the weekend, it may be observed on a different day.)

\begin{tabular}{|ccccccccccc|}
\hline Holiday & $\mathbf{2 0 0 5}$ & $\mathbf{2 0 0 6}$ & $\mathbf{2 0 0 7}$ & $\mathbf{2 0 0 8}$ & $\mathbf{2 0 0 9}$ & $\mathbf{2 0 1 0}$ & $\mathbf{2 0 1 1}$ & $\mathbf{2 0 1 2}$ & $\mathbf{2 0 1 3}$ & $\mathbf{2 0 1 4}$ \\
\hline New Year's & $12 / 31 / 20$ & $1 / 2 / 2006$ & $1 / 1 / 2007$ & $1 / 1 / 2008$ & $1 / 1 / 2009$ & $1 / 1 / 2010$ & $12 / 31 / 20$ & $1 / 2 / 2012$ & $1 / 1 / 2013$ & $1 / 1 / 2014$ \\
Day & 04 & & & & & 10 & & \\
Martin Luther & $1 / 17 / 200$ & $1 / 16 / 200$ & $1 / 15 / 200$ & $1 / 21 / 200$ & $1 / 19 / 200$ & $1 / 18 / 201$ & $1 / 17 / 201$ & $1 / 16 / 201$ & $1 / 21 / 201$ & $1 / 20 / 201$ \\
King, Jr. Day & 5 & 6 & 7 & 8 & 9 & 0 & 1 & 2 & 3 & 4 \\
Presidents' Day & $2 / 21 / 200$ & $2 / 20 / 200$ & $2 / 19 / 200$ & $2 / 18 / 200$ & $2 / 16 / 200$ & $2 / 15 / 201$ & $2 / 21 / 201$ & $2 / 20 / 201$ & $2 / 18 / 201$ & $2 / 17 / 201$ \\
\hline
\end{tabular}




\begin{tabular}{|c|c|c|c|c|c|c|c|c|c|c|}
\hline & 5 & 6 & 7 & 8 & 9 & 0 & 1 & 2 & 3 & 4 \\
\hline & $5 / 30 / 200$ & $5 / 29 / 200$ & $5 / 28 / 200$ & $5 / 26 / 200$ & $5 / 25 / 200$ & $5 / 31 / 201$ & $5 / 30 / 201$ & $5 / 28 / 201$ & $5 / 27 / 201$ & $5 / 26 / 201$ \\
\hline Memorlal Day & 5 & 6 & 7 & 8 & 9 & 0 & 1 & 2 & 3 & 4 \\
\hline $\begin{array}{c}\text { Independence } \\
\text { Day }\end{array}$ & $7 / 4 / 2005$ & 7/4/2006 & 7/4/2007 & $7 / 4 / 2008$ & 7/3/2009 & $7 / 5 / 2010$ & $7 / 4 / 2011$ & 7/4/2012 & 7/4/2013 & 7/4/2014 \\
\hline Labor Day & $9 / 5 / 2005$ & 9/4/2006 & 9/3/2007 & 9/1/2008 & 9/7/2009 & 9/6/2010 & $9 / 5 / 2011$ & $9 / 3 / 2012$ & 9/2/2013 & 9/1/2014 \\
\hline Columbus Day & $\begin{array}{c}10 / 10 / 20 \\
05\end{array}$ & $\begin{array}{c}10 / 9 / 200 \\
6\end{array}$ & $\begin{array}{c}10 / 8 / 200 \\
7\end{array}$ & $\begin{array}{c}10 / 13 / 20 \\
08\end{array}$ & $\begin{array}{c}10 / 12 / 20 \\
09\end{array}$ & $\begin{array}{c}10 / 11 / 20 \\
10\end{array}$ & $\begin{array}{c}10 / 10 / 20 \\
11\end{array}$ & $\begin{array}{c}10 / 8 / 201 \\
2\end{array}$ & $\begin{array}{c}10 / 14 / 20 \\
13\end{array}$ & $\begin{array}{c}10 / 13 / 20 \\
14\end{array}$ \\
\hline Veterans Day & $\begin{array}{c}11 / 11 / 20 \\
05\end{array}$ & $\begin{array}{c}11 / 10 / 20 \\
06\end{array}$ & $\begin{array}{c}11 / 12 / 20 \\
07\end{array}$ & $\begin{array}{c}11 / 11 / 20 \\
08\end{array}$ & $\begin{array}{c}11 / 11 / 20 \\
09\end{array}$ & $\begin{array}{c}11 / 11 / 20 \\
10\end{array}$ & $\begin{array}{c}11 / 11 / 20 \\
11\end{array}$ & $\begin{array}{c}11 / 12 / 20 \\
12\end{array}$ & $\begin{array}{c}11 / 11 / 20 \\
13\end{array}$ & $\begin{array}{c}11 / 11 / 20 \\
14\end{array}$ \\
\hline Thanksgiving & $11 / 24 / 20$ & $11 / 23 / 20$ & $11 / 22 / 20$ & $11 / 27 / 20$ & $11 / 26 / 20$ & $11 / 25 / 20$ & $11 / 24 / 20$ & $11 / 22 / 20$ & $11 / 28 / 20$ & $11 / 27 / 20$ \\
\hline Day & 05 & 06 & 07 & 08 & 09 & 10 & 11 & 12 & 13 & 14 \\
\hline Christmas Day & $\begin{array}{c}12 / 26 / 20 \\
05\end{array}$ & $\begin{array}{c}12 / 25 / 20 \\
06\end{array}$ & $\begin{array}{c}12 / 25 / 20 \\
07\end{array}$ & $\begin{array}{c}12 / 25 / 20 \\
08\end{array}$ & $\begin{array}{c}12 / 25 / 20 \\
09\end{array}$ & $\begin{array}{c}12 / 24 / 20 \\
10\end{array}$ & $\begin{array}{c}12 / 26 / 20 \\
11\end{array}$ & $\begin{array}{c}12 / 25 / 20 \\
12 \\
\end{array}$ & $\begin{array}{c}12 / 25 / 20 \\
13\end{array}$ & $\begin{array}{c}12 / 25 / 20 \\
14\end{array}$ \\
\hline
\end{tabular}

\section{References}

[1] Baker E, Solak S. Climate change and optimal energy technology R\&D policy. European Journal of Operational Research. 2011;213(2):442-54.

[2] Forgó F, Fülöp J, Prill M. Game theoretic models for climate change negotiations. Applications of Mathematical Programming Models. 2005;160(1):252-67.

[3] Georgopoulou E, Sarafidis Y, Mirasgedis S, Zaimi S, Lalas DP. A multiple criteria decision-aid approach in defining national priorities for greenhouse gases emissions reduction in the energy sector. European Journal of Operational Research. 2003;146(1):199-215.

[4] ElMekawy A, Hegab HM, Mohanakrishna G, Elbaz AF, Bulut M, Pant D. Technological advances in $\mathrm{CO} 2$ conversion electro-biorefinery: A step toward commercialization. Bioresource Technology.

[5] Kucukvar M, Egilmez G, Onat NC, Samadi H. A global, scope-based carbon footprint modeling for effective carbon reduction policies: Lessons from the Turkish manufacturing. Sustainable Production and Consumption. 2015;1:47-66.

[6] APEC. Leaders' Declaration - Asia-Pacific Economic Cooperation. 2014. Retrieved from http://www.apec.org/Meeting-Papers/Leaders-Declarations/2014/2014_aelm.aspx.

[7] G20. Leaders' $\quad$ Summit. $2014 . \quad$ Retrieved from https://www.g20.org/australia_2014/leaders_summit.

[8] United Nations. UN Climate Summit. 2014. Retrieved from http://www.un.org/climatechange/summit/.

[9] European Commission. EU Climate Action. 2015. Retrieved from http://ec.europa.eu/clima/citizens/eu/index_en.htm.

[10] The White House. U.S.-China Joint Announcement on Climate Change. 2014. Retrieved from http://www.whitehouse.gov/node/307541.

[11] World Resources Institute. CAIT 2.0 - WRI's Climate Data Explorer. 2014. Retrieved from http://cait2.wri.org/wri/Country\%20GHG\%20Emissions.

[12] U. S. Energy Information Administration. U.S. Energy-Related Carbon Dioxide Emissions 2013. $2014 . \quad$ Retrieved from http://www.eia.gov/environment/emissions/carbon/pdf/2013_co2analysis.pdf.

[13] Hahn H, Meyer-Nieberg S, Pickl S. Electric load forecasting methods: Tools for decision making. European Journal of Operational Research. 2009;199(3):902-7.

[14] California ISO. California ISO Open Access Same-Time Information System (OASIS). 2014. Retrieved from http://oasis.caiso.com/mrioasis/logon.do.

[15] City of Fort Collins. Coincident Peak. 2014. Retrieved from http://www.fcgov.com/utilities/business/rates/electric/coincident-peak.

[16] Cappers P, Goldman C, Kathan D. Demand response in U.S. electricity markets: Empirical evidence. Energy. 2010;35(4):1526-35. 
[17] Moghaddam MP, Abdollahi A, Rashidinejad M. Flexible demand response programs modeling in competitive electricity markets. Applied Energy. 2011;88(9):3257-69.

[18] Gils HC. Economic potential for future demand response in Germany - Modeling approach and case study. Applied Energy. 2016;162:401-15.

[19] O'Connell N, Pinson P, Madsen H, O'Malley M. Benefits and challenges of electrical demand response: A critical review. Renewable and Sustainable Energy Reviews. 2014;39:686-99.

[20] Rizzo C, Lovas T. NRECA-DOE Smart Grid Demonstration Project - Demand Response \& Critical Peak Pricing: Testing the Theoretical Basis for DR. 2013. Retrieved from http://www.nreca.coop/wp-content/uploads/2014/01/NRECA_DOE_DR_CPP_a.pdf.

[21] U. S. Federal Energy Regulatory Commission. A National Assessment of Demand Response Potential. 2009. Retrieved from http://www.ferc.gov/legal/staff-reports/06-09-demandresponse.pdf.

[22] Nelson J, Johnston J, Mileva A, Fripp M, Hoffman I, Petros-Good A, et al. High-resolution modeling of the western North American power system demonstrates low-cost and low-carbon futures. Energy Policy. 2012;43:436-47.

[23] Depuru SSSR, Wang L, Devabhaktuni V. Smart meters for power grid: Challenges, issues, advantages and status. Renewable and Sustainable Energy Reviews. 2011;15(6):2736-42.

[24] European Commission. Commission Recommendation on Preparations for the Roll-Out of Smart Metering Systems. 2012. Retrieved from http://eur-lex.europa.eu/legalcontent/EN/ALL/?uri=CELEX:32012H0148.

[25] Sharma K, Mohan Saini L. Performance analysis of smart metering for smart grid: An overview. Renewable and Sustainable Energy Reviews. 2015;49:720-35.

[26] North American Electric Reliability Corporation. Demand Response Availability Data System Definitions. 2013. Retrieved from http://www.nerc.com/pa/RAPA/dads/Documents/DADS\%20Definitions.pdf.

[27] U. S. Federal Energy Regulatory Commission. Assessment of Demand Response \& Advanced Metering. 2006. Retrieved from http://www.ferc.gov/legal/staff-reports/demand-response.pdf.

[28] Bortolini M, Gamberi M, Graziani A. Dynamic Cost Model for the Energy Mix Planning and the Electrical Grid Management. In: Sharma UC, Prasad R, Sivakumar S, editors. Energy Science \& Technology (Vol. 12). Houston, USA: Studium Press LLC; 2015. p. 289-316.

[29] Woo CK, Li R, Shiu A, Horowitz I. Residential winter $\mathrm{kW}$ h responsiveness under optional timevarying pricing in British Columbia. Applied Energy. 2013;108:288-97.

[30] Bardazzi R, Oropallo F, Pazienza MG. Do manufacturing firms react to energy prices? Evidence from Italy. Energy Economics. 2015;49:168-81.

[31] Aalami HA, Parsa Moghaddam M, Yousefi GR. Evaluation of nonlinear models for time-based rates demand response programs. International Journal of Electrical Power \& Energy Systems. 2015;65:282-90.

[32] Chino Valley Unified School D. Energy Management Success Story: Chino Valley Unified School District. 2012. Retrieved from https://www.sce.com/wps/wcm/connect/f6e4ba65-f0194f9b-849c-4495112d4b9d/CSChinoValley_AA.pdf?MOD=AJPERES.

[33] Coastal Pacific Food Distributors. Energy Management Success Story: Coastal Pacific Food Distributors. 2012. Retrieved from https://www.sce.com/wps/wcm/connect/bc0210e9-60e4-48d38a27-51fdb2f50ce8/CSCoastalPacific_AA.pdf?MOD=AJPERES.

[34] Railex. Energy Management Success Story: Railex. 2012. Retrieved from https://www.sce.com/wps/wcm/connect/109348ba-7680-43f6-839f-

6b7651b583ff/CaseStudy_Railex_AA.pdf?MOD=AJPERES.

[35] The Water Garden. Energy Management Success Story: The Water Garden. 2010. Retrieved from https://www.sce.com/wps/wcm/connect/0a346efc-9d6c-4b1a-8bf5-

caf445b52a5a/WaterGardenCaseStudy.pdf?MOD=AJPERES. 
[36] Braithwait SD, Hansen DG. How Large Commercial and Industrial Customers Respond to Dynamic Pricing-The California Experience. In: Sioshansi FP, editor. Smart Grid. Boston, USA: Academic Press; 2012. p. 289-316.

[37] Faruqui A, Sergici S. Household response to dynamic pricing of electricity: A survey of 15 experiments. Journal of Regulatory Economics. 2010;38(2):193-225.

[38] Herter K. Residential implementation of critical-peak pricing of electricity. Energy Policy. 2007;35(4):2121-30.

[39] Herter K, McAuliffe P, Rosenfeld A. An exploratory analysis of California residential customer response to critical peak pricing of electricity. Energy. 2007;32(1):25-34.

[40] Herter K, Wayland S. Residential response to critical-peak pricing of electricity: California evidence. Energy. 2010;35(4):1561-7.

[41] Aghaei J, Alizadeh MI. Critical peak pricing with load control demand response program in unit commitment problem. Generation, Transmission \& Distribution, IET. 2013;7(7):681-90.

[42] Faruqui A, Sergici S, Akaba L. Dynamic pricing of electricity for residential customers: the evidence from Michigan. Energy Efficiency. 2013;6(3):571-84.

[43] Steve AF, Lullit G, Chris I, Jeff S. Demand impact of a critical peak pricing program: Opt-in and opt-out options, green attitudes and other customer characteristics. The Energy Journal. 2014;35(3).

[44] Wolak F. An experimental comparison of critical peak and hourly pricing: The PowerCentsDC program. In: Seventh Conference on The Economics of Energy Markets, Toulouse, France. 2014:V001T05A4-VT05A4.

[45] Wang J, Bloyd CN, Hu Z, Tan Z. Demand response in China. Energy. 2010;35(4):1592-7.

[46] European Parliament. Effect of Smart Metering on Electricity Prices. 2012. Retrieved from http://www.europarl.europa.eu/document/activities/cont/201202/20120223ATT39186/20120223 ATT39186EN.pdf.

[47] Ipsos MORI. Consumer Experiences of Time of Use Tariffs: Report Prepared for Consumer Focus. 2012. Retrieved September 1, 2014, from http://www.ipsosmori.com/researchpublications/publications/1506/Consumer-Experiences-Of-Time-of-UseTariffs.aspx.

[48] Wahyuda, Santosa B. Dynamic Pricing in Electricity: Research Potential in Indonesia. Procedia Manufacturing. 2015;4:300-6.

[49] Vanthournout K, Dupont B, Foubert W, Stuckens C, Claessens S. An automated residential demand response pilot experiment, based on day-ahead dynamic pricing. Applied Energy. 2015;155:195-203.

[50] U. S. Federal Energy Regulatory Commission. Assessment of Demand Response \& Advanced Metering. 2012. Retrieved from http://www.ferc.gov/legal/staff-reports/12-20-12-demandresponse.pdf.

[51] Lagodimos AG, Leopoulos V. Greedy heuristic algorithms for manpower shift planning. International Journal of Production Economics. 2000;68(1):95-106.

[52] Saksvik IB, Bjorvatn B, Hetland H, Sandal GM, Pallesen S. Individual differences in tolerance to shift work - A systematic review. Sleep Medicine Reviews. 2011;15(4):221-35.

[53] Slomp J, Suresh NC. The shift team formation problem in multi-shift manufacturing operations. European Journal of Operational Research. 2005;165(3):708-28.

[54] D'hulst R, Labeeuw W, Beusen B, Claessens S, Deconinck G, Vanthournout K. Demand response flexibility and flexibility potential of residential smart appliances: Experiences from large pilot test in Belgium. Applied Energy. 2015;155:79-90.

[55] Ericson T. Households' self-selection of dynamic electricity tariffs. Applied Energy. 2011;88(7):2541-7.

[56] Gahm C, Denz F, Dirr M, Tuma A. Energy-efficient scheduling in manufacturing companies: A review and research framework. European Journal of Operational Research. 2016;248(3):744-57. 
[57] Gong X, De Pessemier T, Joseph W, Martens L. An Energy-Cost-Aware Scheduling Methodology for Sustainable Manufacturing. Procedia CIRP. 2015;29:185-90.

[58] Sharma A, Zhao F, Sutherland JW. Econological scheduling of a manufacturing enterprise operating under a time-of-use electricity tariff. Journal of Cleaner Production. 2015;108, Part A:256-70.

[59] Bode J, Churchwell C, George SS. 2012 California Statewide Non-Residential Critical Peak Pricing Evaluation. 2013. Retrieved from http://fscgroup.com/reports/2012-non-res-cppstatewide-evaluation.pdf.

[60] George SS, Bode J, Holmberg S. 2011 California Statewide Non-Residential Critical Peak Pricing Evaluation. 2012. Retrieved from http://fscgroup.com/reports/2011-statewide-cppevaluation.pdf.

[61] George SS, Bode J, Schellenberg J, Holmberg S. 2010 California Statewide Non-Residential Critical Peak Pricing Evaluation. 2011. Retrieved from http://fscgroup.com/reports/2010california-non-residential-cpp-evaluation.pdf.

[62] Wang Y, Li L. A novel modeling method for both steady-state and transient analyses of serial Bernoulli production systems. IEEE Transactions on Systems, Man, and Cybernetics: Systems. 2014.

[63] Wang Y, Li L. Time-of-use based electricity demand response for sustainable manufacturing systems. Energy. 2013;63:233-44.

[64] Wang Y, Li L. Joint production and energy modeling of sustainable manufacturing systems: Challenges and methods. In: ASME 2014 International Manufacturing Science and Engineering Conference, Detroit, Michigan, USA. 2014:V001T05A4-VT05A4.

[65] Wang Y, Li L. Time-of-use based electricity cost of manufacturing systems: Modeling and monotonicity analysis. International Journal of Production Economics. 2014;156:246-59.

[66] Wang Y, Li L. Time-of-use electricity pricing for industrial customers: A survey of U.S. utilities. Applied Energy. 2015;149(0):89-103.

[67] California Public Utilities Commission. Commission Staff Report: Lessons Learned from Summer 2012 Southern California Investor Owned Utilities’ Demand Response Programs. 2013. Retrieved from http://www.cpuc.ca.gov/NR/rdonlyres/523B9D94-ABC4-4AF6-AA09DD9ED8C81AAD/0/StaffReport_2012DRLessonsLearned.pdf.

[68] California Public Utilities Commission. Demand Response. 2014. Retrieved from http://www.cpuc.ca.gov/PUC/energy/Demand+Response/.

[69] Pacific Gas \& Electric. Tariff Book. 2015. Retrieved from www.pge.com/tariffs/ERS.SHTML\#ERS.

[70] Southern California Edison. Rates \& Pricing Choices. 2015. Retrieved from www.sce.com/wps/portal/home/regulatory/tariff-books/rates-pricing-choices.

[71] San Diego Gas \& Electric. Current and Effective Tariffs. 2015. Retrieved from www.sdge.com/rates-regulations/current-and-effective-tariffs/current-and-effective-tariffs.

[72] California Public Utilities Commission. Demand Response Monthly Reports. 2014. Retrieved from http://www.cpuc.ca.gov/PUC/energy/Demand+Response/Monthly+Reports/.

[73] Southern California Edison. Event History. 2014. Retrieved from https://www.sce.openadr.com/dr.website/scepr-event-history.jsf.

[74] U. S. Office of Personnel Management. Operating Status \& Schedules. 2014. Retrieved from http://archive.opm.gov/Operating_Status_Schedules/fedhol/2014.asp.

[75] Cubi E, Doluweera G, Bergerson J. Incorporation of electricity GHG emissions intensity variability into building environmental assessment. Applied Energy. 2015;159:62-9.

[76] Mahone A, Price S, Morrow W. Developing a Greenhouse Gas Tool for Buildings in California: Methodology and User's Mannual v.3. 2010. Retrieved from http://www.ethree.com/public_projects/ghg.html.

[77] Fernandez M, Li L, Sun Z. "Just-for-peak" buffer inventory for peak electricity demand reduction of manufacturing systems. International Journal of Production Economics. 2013;146(1):178-84. 